\title{
Anomalous concentrations of arsenic, fluoride and radon in volcanic- sedimentary aquifers from central Italy: Quality indexes for management of the water resource
}

\author{
D. Cinti ${ }^{\text {a, }}$, O. Vaselli ${ }^{\text {b, c }}$, P.P. Poncia ${ }^{\text {d }}$, L. Brusca ${ }^{\text {e, }}$ F. Grassa ${ }^{\text {e, }}$, M. Procesi ${ }^{\text {a }}$, F. Tassi ${ }^{\text {b, c }}$ \\ a Istituto Nazionale di Geofisica e Vulcanologia, Sezione di Roma 1, Via di Vigna Murata, 605 - 00143 Roma, Italy \\ ${ }^{\mathrm{b}}$ Dipartimento di Scienze della Terra, Università di Firenze, via G. La Pira 4, 50121 Firenze, Italy \\ ${ }^{\text {c } C N R}$ - Istituto di Geoscienze e Scienze della Terra, via G. La Pira 4, 50121 Firenze, Italy \\ d via Camerano 1, 01028 Orte, Italy \\ e Istituto Nazionale di Geofisica e Vulcanologia, Sezione di Palermo, Via U. La Malfa, 153 - 90146 Palermo, Italy
}

\section{A R T I C L E I N F O}

\section{Article history:}

Received 15 February 2019

Received in revised form

19 June 2019

Accepted 11 July 2019

Available online 13 July 2019

\section{Keywords:}

Arsenic

Fluoride

Radon

Central Italy

Ordinary kriging

Quality index

\begin{abstract}
A B S T R A C T
659 water samples from springs and wells in the Sabatini and Vicano-Cimino Volcanic Districts (central Italy) were analyzed for arsenic (As), fluoride $\left(\mathrm{F}^{-}\right)$and radon $\left({ }^{222} \mathrm{Rn}\right)$ concentrations. Waters mostly sourced from a shallow and cold aquifer hosted within volcanic rocks, which represents the main public drinking water supply. Cold waters from perched aquifers within sedimentary formations and thermal waters related to a deep hydrothermal reservoir were also analyzed. The highest concentrations of As and $\mathrm{F}^{-}$were measured in the thermal waters and attributed to their enhanced mobility during waterrock interaction processes at hydrothermal temperatures. Relatively high concentrations of As and $\mathrm{F}^{-}$ were also recorded in those springs and wells discharging from the volcanic aquifer, whereas waters hosted in the sedimentary units showed significantly lower contents. About $60 \%$ (As) and $25 \%\left(\mathrm{~F}^{-}\right.$) of cold waters from the volcanic aquifer exceeded the maximum allowable concentrations for human consumption. Such anomalously high levels of geogenic pollutants were caused by mixing with fluids upwelling through faulted zones from the hydrothermal reservoir. Chemical weathering of volcanic rocks and groundwater flow path were also considered to contribute to the observed concentrations. Cold waters from the volcanic aquifer showed the highest ${ }^{222} \mathrm{Rn}$ concentrations, resulting from the high contents of Rn-generating radionuclides in the volcanic units. Approximately $22 \%$ of these waters exceeded the recommended value for human consumption. A specific Quality Index (QI), comprised between 1 (very low) and 4 (very high), was computed for each water on the basis of $\mathrm{As}^{-\mathrm{F}^{-}}$and ${ }^{222} \mathrm{Rn}$ concentrations and visualized through a spatial distribution map processed by means of geostatistical techniques. This map and the specific As, $\mathrm{F}^{-}$and ${ }^{222} \mathrm{Rn}$ maps can be regarded as useful tools for water management by local authorities to both improve intervention plans in contaminated sectors and identify new water resources suitable for human consumption.
\end{abstract}

(C) 2019 Elsevier Ltd. All rights reserved.

\section{Introduction}

The peri-Tyrrhenian sector of central Italy, from southern Tuscany to northern Latium, hosts large ( $>1000 \mathrm{~km}^{2}$ wide) Quaternary potassic and ultrapotassic volcanic districts (Vulsini, VicanoCimino, Sabatini and Colli Albani; Conticelli and Peccerillo, 1992). These systems are currently considered in a dormant stage, since

\footnotetext{
this paper has been recommended for acceptance by Dr. Sarah Harmon.

* Corresponding author.

E-mail address: daniele.cinti@ingv.it (D. Cinti).
}

the last eruptive event dated back 36 ka (Marra et al., 2009). As a result, volcanic hazard in these areas does not include any potentially dangerous eruptive phenomena and secondary eruptionrelated processes (e.g. volcanic earthquakes, lahars or tsunamis), but medium-to long-term phenomena which are active since the end of the volcanic activity. Among them, local uprising of deeporiginated hydrothermal fluids and their interaction with volcanic rocks are able to cause groundwater pollution and the consequent deterioration of the quality of water resources for human consumption, as largely documented for active or dormant volcanoes worldwide (e.g. Ellis and Mahon, 1977; Barnes, 1997; Aiuppa et al., 2000, 2005; Dall'Aglio et al., 2001; Vivona et al., 2007). 
The Sabatini Volcanic District (SVD) and the Vicano-Cimino Volcanic District (VCVD) are two wide $\left(\sim 2800 \mathrm{~km}^{2}\right)$ and densely populated areas $(\sim 500,000$ inhabitants $)$ in the Latium region, where the regional groundwater circulation within volcanic rocks is the main source of cold and fresh waters used as drinking water supply. Recent studies focused on these areas highlighted that groundwater quality can locally be compromised due to natural processes such as: $i$ ) excess of solutes, which play an essential role for the human health status, through at specific concentration ranges (e.g. fluoride; Vivona et al., 2007; Preziosi et al., 2016), ii) occurrence of toxic contaminants (e.g. arsenic and heavy metals; Angelone et al., 2009; Baiocchi et al., 2013; Armiento et al., 2015; Cinti et al., 2015; Viaroli et al., 2016), and iii) anomalous concentrations of radioactive isotopes (e.g. radon; Cinti et al., 2013). Since these elements can have a significant environmental impact and harmful effects on human health, actions aimed at mitigating the contamination of the water resources through their removal (e.g., Katsoyiannis and Zouboulis, 2004; Meenakshi and Maheshwari, 2006; Mohan and Pittman, 2007; Vaklavikov et al., 2008; Jagtap et al., 2012; Cothern and Rebers, 2014) and identifying new water resources free of geogenic pollution have become increasingly important. In an effort to provide an adequate supply of safe water for household consumption, geochemical characterization of groundwater resources in volcanic-hydrothermal areas and geochemical mapping of geogenic contaminants represent essential steps to define the necessary tools for decision-making in territorial planning (e.g. Rahman et al., 2005; Angelone et al., 2009; Baiocchi et al., 2013; Alonso et al., 2015; Cinti et al., 2015).

As far as the study area is concerned, a few geochemical maps on the As spatial distribution, though limited to the VCVD, were published by Vivona et al. (2007), Angelone et al. (2009), Armiento et al. (2015) and Cinti et al. (2015) whereas maps related to the distribution of $\mathrm{F}^{-}$(Vivona et al., 2007; De Rita et al., 2011; Preziosi et al., 2016) and ${ }^{222} \mathrm{Rn}$ (Cinti et al., 2013) were poorly constrained. To fill this gap, in this paper spatial distribution maps of As, $\mathrm{F}^{-}$and ${ }^{222} \mathrm{Rn}$ concentrations, based on a large and original dataset consisting of 659 water samples collected in the SVD and VCVD, are shown and discussed to $i$ ) investigate the sources and the main factors controlling their geochemical behavior and distribution and ii) evaluate the contribution of these pollutants due to the geogenic source. In addition, in the framework of the model of the Water Safety Plans (WHO, 2011), aimed at ensuring rigorous control strategies on water quality for health protection, a Quality Index (QI: from 1, very low, to 4 , very high) for each water sample was defined to establish the degree of natural contamination of the water resource. Finally, a geostatistical approach was applied to build the relative distribution maps to be used as a valid tool for water management by policy makers.

\section{Origin and behavior of arsenic, fluoride and radon in natural waters}

\subsection{Arsenic}

Arsenic (As) is a toxic element ubiquitously found in the environment (Nordstrom, 2002; Smedley and Kinniburgh, 2002; WHO, 2011) and classified as a carcinogenic (IARC, 2004). Acute and chronic toxic effects on populations exposed to high As concentrations in drinking water (WHO, 2011) promoted the legislative revision concerning the quality standards for drinking waters (Council Directive 98/83/EC), which lowered the As concentration limit from 50 to $10 \mu \mathrm{g} / \mathrm{L}$ and imposed a drastic change in the management of groundwater resources. Alluvial, deltaic, arid and semi-arid oxidising environments and volcanic-hydrothermal systems are the main natural settings prone to the occurrence of As in groundwater (e.g. Smedley and Kinniburgh, 2002; Stüben et al., 2003; Norra et al., 2005). In volcanic-hydrothermal systems, Asrich groundwater systems are mostly related to the presence of geothermal fluids and volcanic gases, which can alter As-bearing minerals (e.g. sulfides, oxides, arsenates, arsenites) from volcanic rocks (Ballantyne and Moore, 1988; Webster, 1999; Aiuppa et al., 2006). Natural As contamination of drinking waters has widely been documented to occur worldwide (e.g. Smedley and Kinniburgh, 2002; Stüben et al., 2003; Guo and Wang, 2005; Norra et al., 2005; Bundschuh et al., 2009) including Italy (e.g. Aiuppa et al., 2003; Angelone et al., 2009; Baiocchi et al., 2013; Barbieri et al., 2014; Armiento et al., 2015; Cinti et al., 2015). Up to 150 million people are thought to be exposed to anomalous concentrations of As, although this evaluation is likely underestimated since new contaminated areas are often recognized (Ravenscroft et al., 2009). In aqueous solutions, As mostly occurs in inorganic forms, as oxyanions of arsenite $\mathrm{As}(\mathrm{III})$ or arsenate $\mathrm{As}(\mathrm{V})(\mathrm{WHO}$, 2011), and is easily mobilized at $\mathrm{pH}$ between 6.5 and 8.5 , being this interval typically shown by groundwater. Although $\mathrm{As}(\mathrm{V})$ is favored in oxidized environments and As(III) at anaerobic conditions, they are reported to be coexisting (Smedley and Kinniburgh, 2002; Oremland and Stolz, 2003). The As(III) compounds are considered to be more toxic and more difficult to be removed than those of $\mathrm{As}(\mathrm{V})$ (Bissen and Frimmel, 2003).

\subsection{Fluoride}

Fluorine is the 13th most abundant element in the Earth's crust (Weinstein and Davison, 2003), and its major pathway to humans is through drinking water as fluoride $\left(\mathrm{F}^{-}\right)$. Its optimal range for human health status is considered to be between 0.5 and $1.5 \mathrm{mg} / \mathrm{L}$, a concentration range that is beneficial to prevent dental caries and strengthen bones (Fabiani et al., 1999; WHO, 2011). Artificial fluoridation of public supplied waters is a common practice used in many countries when $\mathrm{F}^{-}$concentrations are below $<0.5 \mathrm{mg} / \mathrm{L}$. On the other hand, chronic ingestion at high doses $(>1.5 \mathrm{mg} / \mathrm{L})$ of $\mathrm{F}^{-}$ can lead to adverse effects, including dental and skeletal fluorosis, whose severity is roughly proportional to its concentration in water (Edmunds and Smedley, 1996; Ozsvath, 2009). Endemic fluorosis is a major concern in many regions worldwide (e.g. Ren and Shugin, 1988; Choubisa, 1999; Reimann et al., 2003; Soto-Rojas et al., 2004), whereas in Italy fluorosis is limited to a few areas in Sicily (Fradà et al., 1969). High $\mathrm{F}^{-}$concentrations in groundwater are generally related to natural sources, whereas only occasionally is of anthropogenic origin (Ozsvath, 2009; WHO, 2011). The occurrence of $\mathrm{F}^{-}$in volcanic-hydrothermal fluids is related to $i$ ) release of magmatic fluorine as HF through volcanic degassing, ii) upwelling of geothermal fluids and iii) water-rock interaction processes involving F-rich minerals (e.g., D'Alessandro, 2006; Sawyer and Opperheimer, 2006; Ozsvath, 2009; De Rita et al., 2011). High fluorine contents are generally found in volcanic rocks and hydrothermal deposits commonly associated with fluorite $\left(\mathrm{CaF}_{2}\right)$, fluorapatite $\left(\mathrm{Ca}_{5}\left(\mathrm{PO}_{4}\right)_{3} \mathrm{~F}\right)$ and F-rich micas and/or amphiboles (where $\mathrm{F}^{-}$largely replaces $\mathrm{OH}^{-}$within the mineral structures). Dissolved $\mathrm{F}^{-}$concentrations are usually controlled by water temperature, $\mathrm{pH}$, presence of complexing/precipitating ions and colloids, solubility of F-bearing minerals, residence time, and climate (Ozsvath, 2009). Accordingly, waters characterized by high temperatures and acidic conditions favor the presence of dissolved fluoride in volcanic aquifers.

\subsection{Radon}

Natural radionuclides, continuously produced in the Earth's 
crust by ${ }^{238} \mathrm{U},{ }^{235} \mathrm{U}$ and ${ }^{232}$ Th radioactive chains and ${ }^{40} \mathrm{~K}$, that is a long-lived radioactive isotope of elemental $\mathrm{K}$, represent the main natural source of ionizing radiation received by the human population worldwide (UNSCEAR, 2008). Among them, radon-222 $\left({ }^{222} \mathrm{Rn}\right)$, formed within the ${ }^{238} \mathrm{U}$ chain by decay of ${ }^{226} \mathrm{Ra}$, is the main radioactivity source of groundwater. Radon has three radioactive isotopes but only ${ }^{222} \mathrm{Rn}$ is of interest having a half-life of 3.8 days, since ${ }^{219} \mathrm{Rn}$ and ${ }^{220} \mathrm{Rn}$ are short-lived isotopes $(3.8 \mathrm{~s}$ and $55.6 \mathrm{~s}$, respectively). The health hazard associated with elevated concentrations of ${ }^{222} \mathrm{Rn}$ in drinking water mostly arises from inhalation of radon discharged from tap water in indoor air and, to a lesser extent, from direct ingestion. Radon is classified as a human carcinogen, whose long-term exposure via inhalation represents the second cause of lung cancer after smoking (Dubois, 2005). There is also evidence that prolonged ingestion of ${ }^{222} \mathrm{Rn}$-rich water can cause stomach cancer (UNSCEAR, 2008; WHO, 2011). Following the EU guidelines on radioactive substances in water intended for human consumption (Council Directive 2013/51/ EURATOM), Italy has recently set the concentration limit for ${ }^{222} \mathrm{Rn}$ in drinking water at $100 \mathrm{~Bq} / \mathrm{L}$ (Legislative Decree $\mathrm{n}^{\circ}$ 28/2016), which represents the action level (Synnott and Fenton, 2005) above which an intervention is recommended to improve the quality of water to accomplish the requirements for the protection of human health. An additional reference level of $1000 \mathrm{~Bq} / \mathrm{L}$, i.e. ${ }^{222} \mathrm{Rn}$ concentration above which some specific decision should be taken, has also been defined. The occurrence of $U$ - and Ra-bearing minerals of rocks and the degree of rock fracturing are the main factors influencing the ${ }^{222} \mathrm{Rn}$ concentrations of groundwater (e.g. Loomis et al., 1988; Ball et al., 1991; Vinson et al., 2009; Cinti et al., 2013; Alonso et al., 2015). Water temperature also affects the Rn concentration, since the ${ }^{222} \mathrm{Rn}$ solubility decreases as water temperature increases (Andrews and Wood, 1974; Roba et al., 2000; Clever, 2013). In addition to geogenic factors, the ${ }^{222} \mathrm{Rn}$ concentration in drinking water is affected by the water distribution system and water purification operations, whereas the contribution of dissolved ${ }^{222} \mathrm{Rn}$ to the total indoor-airborne concentration inside the dwelling is influenced by the amount of water used, volume of the dwelling and ventilation rate (Hopke et al., 2000; UNSCEAR , 2008).

\section{Geodynamic evolution, hydrological and petrological settings}

The study area includes VCVD and the SVD, two volcanic districts pertaining to the Roman Magmatic Province (Conticelli and Peccerillo, 1992), and the Tolfa mountains, where an intrusive body of the Tuscan Magmatic Province (i.e. the Tolfa Dome Complex; Cimarelli and De Rita, 2006) emplaced on a sedimentary basement (Fig. 1). The magmatic activity from southern Tuscany and northern Latium, along the Tyrrhenian margin of the Apennine chain, took place during the Neogene as a consequence of the postorogenic crustal extension occurring at the back of the eastwardmigrating Apennine belt. Strong crustal thinning $(<25 \mathrm{~km}$; Scrocca et al., 2003) and high heat flow (locally $>200 \mathrm{~mW} / \mathrm{m}^{2}$; Della Vedova et al., 2001) were also induced by extensional processes.

A space-time migration from $\mathrm{W}$ to $\mathrm{E}$ of the magmatic products was observed (Serri et al., 1993) and associated with changes in the nature of the erupted magmas. Initially, magmatism was characterized by crustal metasomatized acidic products (Tuscan Magmatic Province), lately evolving to more under-saturated alkali-potassic magmas (Roman Magmatic Province) (Peccerillo, 2017). Rhyolites, rhyodacites and trachydacites, mostly emplaced as the Tolfa-Cerite-Manziate (3.5 Ma) and the Cimini (1.3-0.9 Ma) dome complexes, represented the acid products in the study area (Fig. 1). The Roman-type magmatism, generating the Sabatini (0.8-0.09 Ma; Cioni et al., 1993; De Rita et al., 1996) and Vicano
(0.4-0.1 Ma; Laurenzi and Villa, 1987) complexes, produced volcanic rocks of potassic (thachybasalts, trachytes) and ultrapotassic (leucites, tephrites, phonolites) composition. The pre-volcanic substratum of SVD and VCVD is composed by Mesozoic limestones and Cenozoic siliciclastic turbidite deposits (i.e. flysch units). These basement rocks were folded and thrusted mainly by dominant NW- and minor NE-striking extensional faults arranged in a horst and graben pattern (Barberi et al., 1994; Acocella and Funiciello, 2006). The structural lows of the Meso-Cenozoic units were filled by Neogene marine and continental clastic sediments (Baldi et al., 1974; Barberi et al., 1994).

Two main aquifer systems at different depths are distinguished in the study area: $i$ ) a shallow circulation within the volcanic rocks and ii) a deep circulation within the regional hydrothermal reservoir, which is confined into the carbonate units and separated from the former by low-permeability Cenozoic and Neogene clastic deposits (Capelli et al., 2005; Manca et al., 2017). Locally, discontinuous perched aquifers of limited extent occur within the siliciclastic sequence. The volcanic aquifer is made up of both fractured (lava flows) and porous (pyroclastic units) layers, the latter showing marked lateral and vertical heterogeneities according to the depositional environment. Although volcanic units are inhomogeneous in terms of geometry and hydraulic properties, at regional scale all the volcanic layers can be regarded as large continuous multi-layered aquifer, sustained by the less permeable pre-volcanic deposits (Manca et al., 2017). Thermal and mineral springs abundantly emerge from the volcanic and sedimentary outcrops (Fig. 1), especially in correspondence of tectonic disturbances, since fractures and faults act as preferential pathways for the rising of fluids of deep origin. By a hydrogeological point of view, groundwater circulation mainly reflects the volcanic structures since radially flowing waters from the higher sectors of each volcanic district were observed (Capelli et al., 2005). The volcanic aquifer mainly emerges from both linear, continuously supplying watercourses of limited length but characterized by constant flow, and punctual springs. The lakes of Vico, Bracciano and Martignano represent the level of the volcanic aquifer, whereas Lake Monterosi is related to a perched aquifer (Capelli et al., 2005; Baiocchi et al., 2006; Manca et al., 2017).

Concentrations of $\mathrm{As}, \mathrm{F}$ and ${ }^{222} \mathrm{Rn}$ in rocks from the study area show significant differences when the volcanic and the sedimentary domains are taken into account. High As contents characterize the volcanic rocks from the Roman Magmatic Province (up to 42 and $187 \mathrm{mg} / \mathrm{kg}$ in lavas and pyroclastic deposits, respectively; Vivona et al., 2007; Armiento et al., 2015; Piscopo et al., 2018). Noteworthy, these values are significantly higher than those reported for other Italian volcanic systems (ranging from 1 to $12 \mathrm{mg}$ / kg; Allard et al., 2000; Paone et al., 2001; Aiuppa et al., 2003). Although specific chemical analyses were not conducted on sedimentary rocks from the study area, it can be assumed that the average As concentrations of sandstones is very low (ranging up to $4 \mathrm{mg} / \mathrm{kg}$; Webster, 1999; Smedley and Kinniburgh, 2002). As far as the carbonatic rocks (limestones, travertines) are concerned, several studies (e.g. Le Guern et al., 2003; Bardelli et al., 2011; Costagliola et al., 2013; Winkel et al., 2013) reported the occurrence of As-bearing calcite $\left(\mathrm{CaCO}_{3}\right)$ derived from the incorporation of As into the mineral structure through the substitution of As oxyanions $\left(\mathrm{AsO}_{3}^{3-}\right)$ for the carbonate group $\left(\mathrm{CO}_{3}^{2-}\right)$. Since carbonates represent the hosting rocks of the hydrothermal reservoir and large travertine deposits occur in the study area (Pentecost, 1995), they are to be considered as potential sources of high As concentrations. Fluorine is widely present in the Quaternary volcanic districts of central Italy. Since average F contents are in the range of $100-300 \mathrm{mg} / \mathrm{kg}$ in sedimentary rocks and up to $600 \mathrm{mg} / \mathrm{kg}$ in volcanic rocks (Ellis and Mahon, 1977; Faure, 1991), concentration levels higher than 


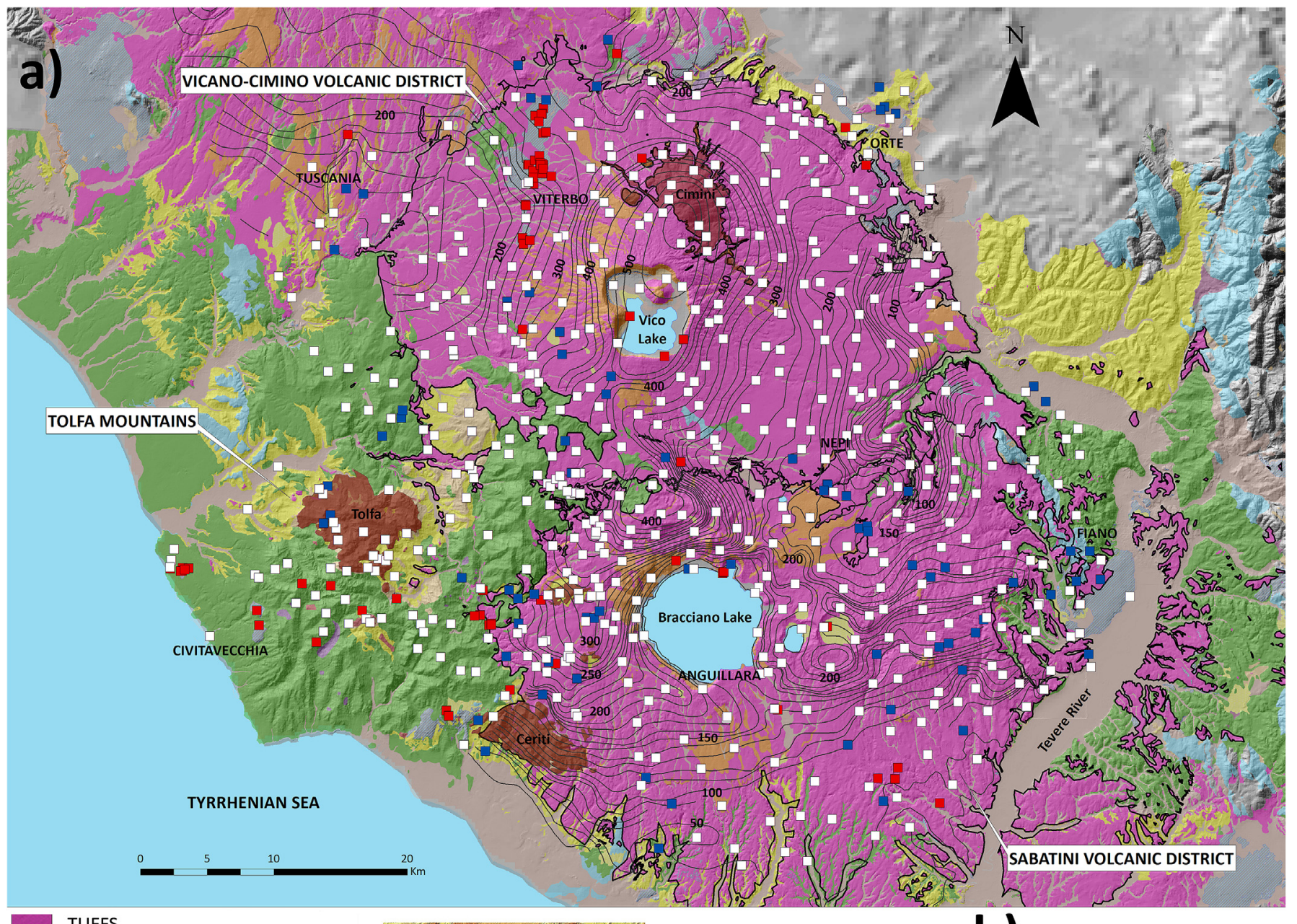

\begin{tabular}{|c|c|}
\hline & $\begin{array}{l}\text { TUFFS Volcanic units (Pleistocene) } \\
\text { LAVAS }\end{array}$ \\
\hline & LAVA DOMES (Pleistocene) \\
\hline & CLAYS (Plio-Pleistocene) \\
\hline & CONGLOMERATES (Mio-Pliocene) \\
\hline & LIGURIAN s.I. (Creta-Oligocene) \\
\hline & CARBONATES (Mesozoic) \\
\hline & ANHYDRITES (Triassic) \\
\hline & TRAVERTINES (Holoc.-Pleistocene) \\
\hline & ALLUVIAL DEPOSITS (Holocene) \\
\hline$\square$ & CO2-RICH COLD WATERS \\
\hline 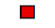 & THERMAL WATERS \\
\hline$\square$ & COLD WATERS \\
\hline 1900 & $\begin{array}{l}\text { CONTOUR LINES OF THE VOLCANIC } \\
\text { AQUIFER (m a.s.I.) }\end{array}$ \\
\hline
\end{tabular}
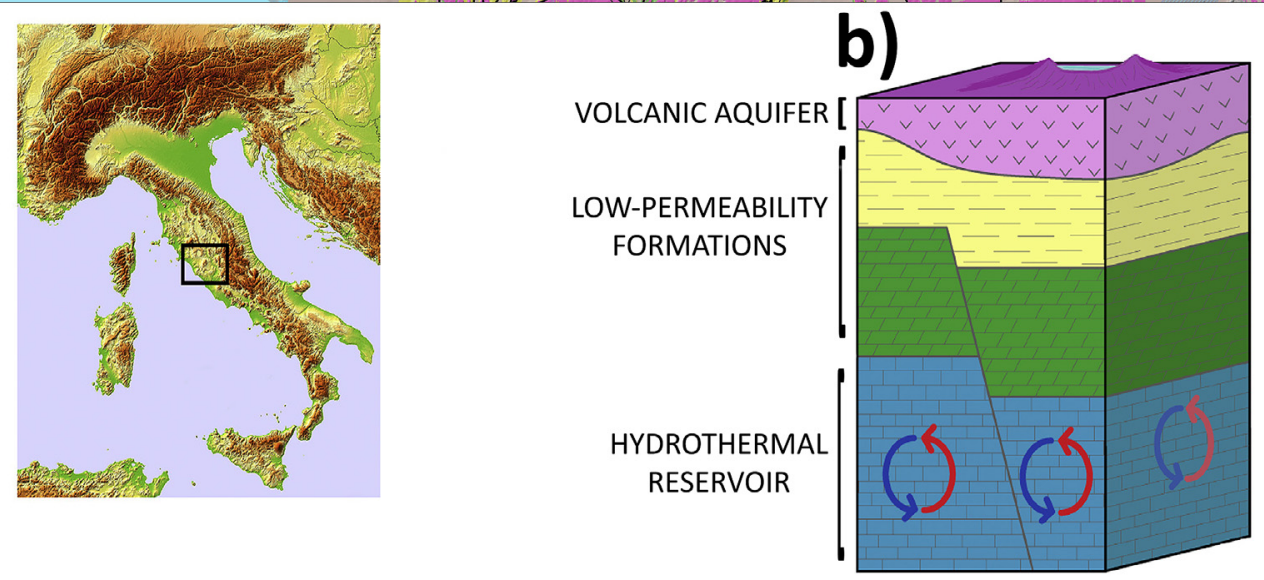

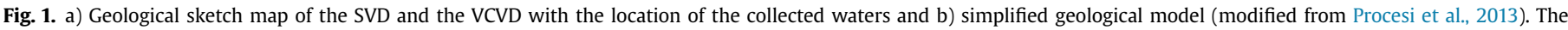
potentiometric surface of the basal aquifer is taken from Capelli et al. (2005).

$800 \mathrm{mg} / \mathrm{kg}$ in the SVD and VCVD rocks (De Rita et al., 2011) are considered anomalous. The F contents in the rocks from the study area are not homogeneously distributed. The highest concentrations were found in correspondence to hydrothermally altered volcanic rocks and neo-forming travertines, where the presence of regional and/or local fracture systems favor the upwelling of F-rich fluids from the regional hydrothermal reservoir. The concentrations of fluorine tend to decrease with distance from hydrothermal alteration areas. Sedimentary deposits are usually characterized by low contents (De Rita et al., 2011). Radiometric characterization of volcanic and sedimentary rocks from SVD and VCVD (Trevisi et al., 2005) showed that the mean content of Rn-generating radionuclides ${ }^{238} \mathrm{U}$ and ${ }^{226} \mathrm{Ra}$ of tuffs (160 and $147 \mathrm{~Bq} / \mathrm{kg}$, respectively) and lavas (134 and $124 \mathrm{~Bq} / \mathrm{kg}$, respectively) from the Roman Magmatic Province is significantly higher than that of sedimentary formations (up to 49 and $24 \mathrm{~Bq} / \mathrm{kg}$, respectively) (Locardi and Mittempergher, 1971; Voltaggio et al., 2001). 


\section{Methods}

Water samples $(\mathrm{N}=659)$ collected from springs, domestic and municipal wells and homogeneously distributed over an area of about $2800 \mathrm{~km}^{2}$ (Fig. 1) were analyzed for $\mathrm{As}, \mathrm{F}^{-}$and ${ }^{222} \mathrm{Rn}$ concentrations. Other physical, chemical and isotopic data were analyzed and discussed elsewhere (Cinti et al., 2011, 2014, 2017). Waters were sampled from $i$ ) the cold and shallow volcanic aquifer, which is the main local source of drinking water supplies, ii) the cold and shallow perched aquifers hosted in permeable layers of the sedimentary deposits and iii) the deep hydrothermal reservoir hosted in the carbonate formations.

Samples for the analysis of As were filtered (with $0.45 \mu \mathrm{m}$ filters) and acidified (to $\mathrm{pH}<2$ with ultra-pure $\mathrm{HNO}_{3}$ ) into pre-cleaned (with diluted Suprapur $\mathrm{HNO}_{3}$ ) polyethylene tubes, and then analyzed by inductively coupled plasma mass-spectrometry (ICPMS; Agilent 7500ce). The analytical error for ICP-MS was $<10 \%$. Fluoride was analyzed on filtered $(0.45 \mu \mathrm{m})$ samples by ionchromatography (IC; Dionex DX-500 and Thermo Scientific Dionex ICS-900). The analytical error for IC was $<5 \%$. Samples for dissolved ${ }^{222} \mathrm{Rn}$ were collected in a $0.6 \mathrm{~L}$ bottle equipped with a watertight cap provided with an expansion chamber, in order to allow an air bubble inside the bottle, and inserted in a closed circuit with a pump and an Activated Charcoal Collector (Mancini et al., 2000). The ${ }^{222} \mathrm{Rn}$-enriched air stripped from water was pumped from the expansion chamber of the bottle and then adsorbed into the activated charcoal. Collectors were analyzed by a low background $\gamma$-spectrometer using a $\mathrm{NaI}(\mathrm{Tl})$ scintillator. The ${ }^{222} \mathrm{Rn}$ concentration was obtained by detecting the $\gamma$ radiation deriving from the radon decay products ${ }^{214} \mathrm{~Pb}$ and ${ }^{214} \mathrm{Bi}$ and correcting the gross datum by a decay factor that accounted for radon decay from the sampling time to the analyzing time (Mancini et al., 2000).

All analytical data were processed by means of descriptive basic statistics, while graphical representations (i.e. box-plots, Q-Q plots) were used to characterize the whole population and the related subsets with respect to the geochemical parameters (As, $\mathrm{F}^{-}$and ${ }^{222} \mathrm{Rn}$ concentrations). The analytical data were geostatistically treated through a variogram surface analysis and kriging estimation (Krige, 1966; Matheron, 1971; Goovaerts, 1997). Experimental directional variograms provided $i$ ) a description of the scale and pattern of spatial variation of the As, $F^{-}$and ${ }^{222} \mathrm{Rn}$ concentrations and $i i)$ the directional differences between the major and minor anisotropy ellipse axes for the kriging estimation, even considering the geological information. This representation allows to consider the anisotropy of the variables and validate the presence of spatial autocorrelation among the experimental data. The common features of the directional semi-variograms are, as follows: $i$ ) roughly linear growth of the semi-variance $\gamma(\mathrm{h})$ up to a certain lag distance (range) over which the semi-variance $\gamma(\mathrm{h})$ remains approximatively constant at a specific value (sill), which means that only sample locations separated by distances closer than the range are spatially correlated; $i i)$ nugget effect, i.e. for lag $=0$ the semivariance $\gamma(\mathrm{h})>0$, due to the measurement errors and/or spatial variations occurring at distances smaller than the sampling step. Ordinary kriging was applied to produce estimation maps for the log-transformed variables. At a preliminary phase, maps were backtransformed into original variable values and no further adjustments (e.g. removal of outliers) were carried out on maps after kriging process.

\section{Results}

\subsection{Basic statistics}

Arsenic, $\mathrm{F}^{-}$and ${ }^{222} \mathrm{Rn}$ concentrations, geographical coordinates, emergence and aquifer type and a map reporting the labelled sampling points are provided as electronic supplementary material (SM 1 and SM 2, respectively). Basic statistics (Table 1) highlights that the experimental data of the three elements have a positive skewness and are characterized by non-normal distribution. Three different subsets were extracted from the whole dataset, as follows: i) cold waters from the volcanic aquifer, ii) cold waters from the shallow perched sedimentary aquifers and iii) thermal waters from the deep hydrothermal reservoir (Table 1). Cold waters circulating within the volcanic and sedimentary formations were first recognized on the basis of the outcropping unit at the discharge point (Fig. 1) and, where available, the well stratigraphy. Where such a criterion proved to be uncertain, e.g. at the border between volcanic and sedimentary formations, waters from the two groups were distinguished according to their chemical-physical features at the sampling site (e.g., Cinti et al., 2011). Experimental data relative to the three subsets (Table 1) show a positive skewness for each variable, except for the subset representing the $\mathrm{F}^{-}$concentrations in thermal waters, which shows a normal distribution. Box-plots (Fig. 2a-c) indicate that the thermal waters have the highest concentrations and the largest dispersion for As and $\mathrm{F}^{-}$, with median values of $77.3 \mu \mathrm{g} / \mathrm{L}$ and $2.15 \mathrm{mg} / \mathrm{L}$ and IQR (Inter Quartile Range) values of $321 \mu \mathrm{g} / \mathrm{L}$ and $1.34 \mathrm{mg} / \mathrm{L}$, respectively (Table 1 ). Waters from the volcanic aquifer displayed concentrations and dispersions (median values of $13.2 \mu \mathrm{g} / \mathrm{L}, 0.72 \mathrm{mg} / \mathrm{L}$ and $54.0 \mathrm{~Bq} / \mathrm{L}$ and IQR values of $18.3 \mu \mathrm{g} / \mathrm{L}, 1.21 \mathrm{mg} / \mathrm{L}$ and $63.4 \mathrm{~Bq} / \mathrm{L}$ for $\mathrm{As}, \mathrm{F}^{-}$and ${ }^{222} \mathrm{Rn}$, respectively), relatively higher than those recorded for the sedimentary

Table 1

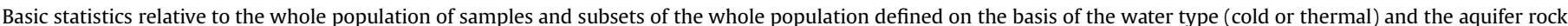
(volcanic or sedimentary). Concentrations are expressed as $\mu \mathrm{g} / \mathrm{L}(\mathrm{As}), \mathrm{mg} / \mathrm{L}\left(\mathrm{F}^{-}\right)$and $\mathrm{Bq} / \mathrm{L}\left({ }^{222} \mathrm{Rn}\right)$.

\begin{tabular}{|c|c|c|c|c|c|c|c|c|c|c|c|}
\hline & No. of observations & Min. & Max. & Q1 & Median & Q3 & Inter-quartile range & Average & Std-dev. & Skewness & Kurtosis \\
\hline \multicolumn{12}{|l|}{ Arsenic } \\
\hline Whole population & 658 & 0.01 & 1514 & 3.78 & 10.6 & 23.2 & 19.5 & 39.4 & 115 & 6.53 & 58.1 \\
\hline Cold-volcanic & 458 & 0.07 & 296 & 6.01 & 13.2 & 24.3 & 18.3 & 20.4 & 28.8 & 5.54 & 43.0 \\
\hline Cold-sedimentary & 127 & 0.01 & 17.6 & 0.36 & 1.06 & 4.28 & 3.93 & 2.67 & 3.31 & 1.71 & 3.02 \\
\hline Thermal waters & 73 & 0.01 & 1514 & 15.8 & 77.3 & 337 & 321 & 223 & 278 & 1.98 & 5.60 \\
\hline \multicolumn{12}{|l|}{ Fluoride } \\
\hline Whole population & 658 & 0.01 & 16.5 & 0.23 & 0.68 & 1.57 & 1.34 & 1.09 & 1.33 & 4.44 & 38.8 \\
\hline Cold-volcanic & 458 & 0.01 & 16.5 & 0.27 & 0.72 & 1.48 & 1.21 & 1.09 & 1.38 & 5.20 & 44.3 \\
\hline Cold-sedimentary & 127 & 0.01 & 3.81 & 0.11 & 0.23 & 0.55 & 0.44 & 0.43 & 0.62 & 3.62 & 14.9 \\
\hline $\begin{array}{l}\text { Thermal waters } \\
\text { Radon }\end{array}$ & 73 & 0.09 & 8.65 & 1.65 & 2.15 & 2.99 & 1.34 & 2.19 & 1.21 & 1.82 & 9.47 \\
\hline Whole population & 640 & 0.10 & 797 & 10.9 & 36.9 & 76.4 & 65.4 & 60.5 & 82.3 & 3.77 & 21.2 \\
\hline Cold-volcanic & 446 & 0.77 & 797 & 30.0 & 54.0 & 93.4 & 63.4 & 78.2 & 85.1 & 3.37 & 17.1 \\
\hline Cold-sedimentary & 123 & 0.54 & 44 & 3.88 & 6.37 & 12.8 & 8.91 & 9.11 & 8.06 & 1.88 & 4.53 \\
\hline Thermal waters & 71 & 0.10 & 698 & 3.02 & 9.11 & 34.5 & 31.5 & 38.7 & 92.5 & 5.54 & 35.4 \\
\hline
\end{tabular}



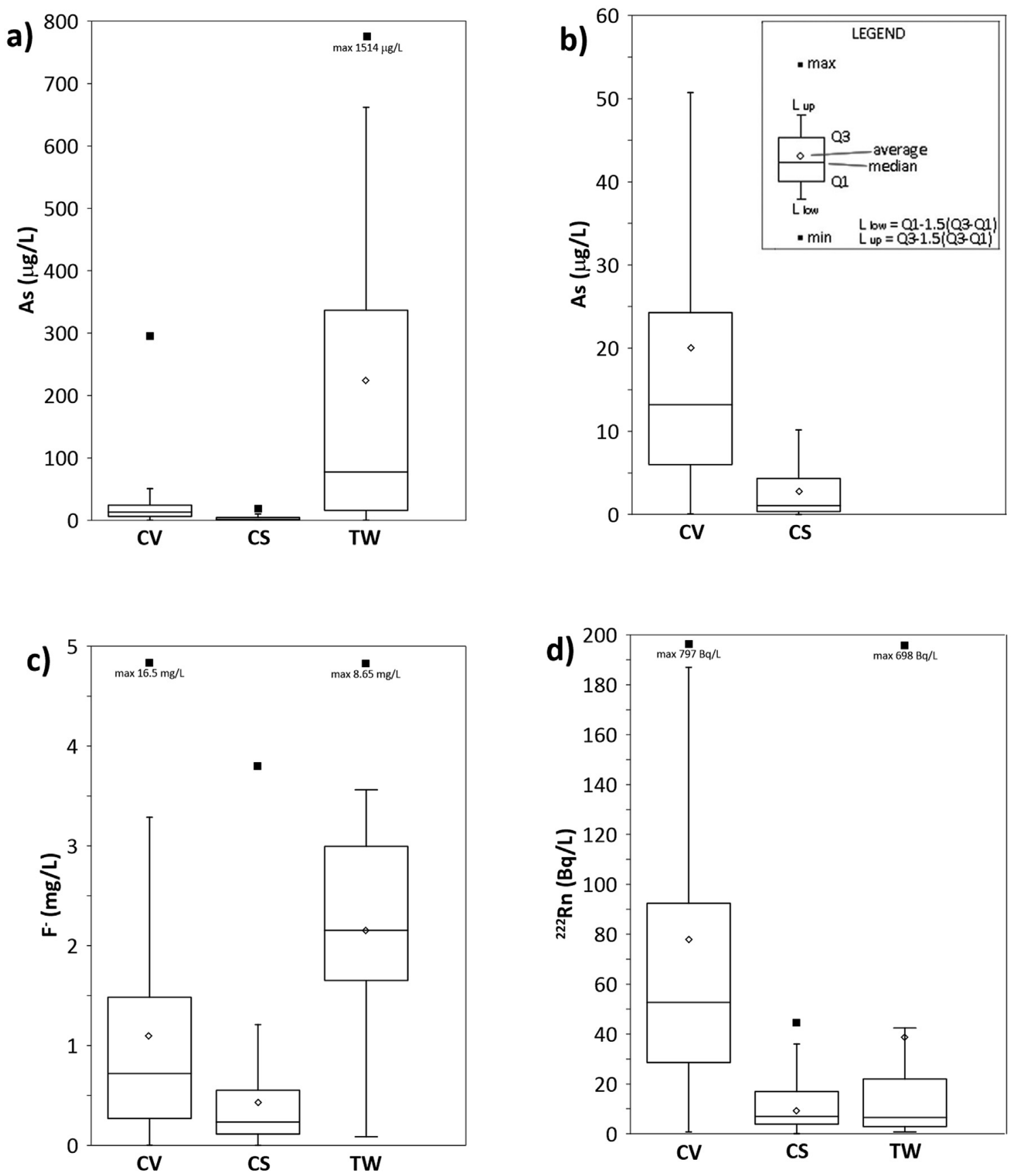

Fig. 2. Box plot of the subsets of the whole sampling population for $A s(a, b), F^{-}(c)$ and ${ }^{222} \mathrm{Rn}(d) . C V=$ cold volcanic, $C S=$ cold sedimentary, TW $=$ thermal waters.

waters, which were characterized by the lowest concentrations and dispersions for the three variables (median values of $1.06 \mu \mathrm{g} / \mathrm{L}$, $0.23 \mathrm{mg} / \mathrm{L}$ and $6.37 \mathrm{~Bq} / \mathrm{L}$ and IQR values of $3.93 \mu \mathrm{g} / \mathrm{L}, 0.44 \mathrm{mg} / \mathrm{L}$ and $8.91 \mathrm{~Bq} / \mathrm{L}$ for $\mathrm{As}, \mathrm{F}^{-}$and ${ }^{222} \mathrm{Rn}$, respectively; Fig. $2 \mathrm{a}-\mathrm{d}$ ).

\subsection{Geostatistical analysis and kriging}

A comprehensive geostatistical approach was elaborated in order to provide insights into the spatial distribution of As, $\mathrm{F}^{-}$and ${ }^{222} \mathrm{Rn}$ and to construct distribution maps by means of ordinary kriging. Since the concentrations of $A s, F^{-}$and ${ }^{222} \mathrm{Rn}$ show nonnormal distributions (i.e. the assumption of statistical normality is not satisfied) a log-transformation of the variables was applied to obtain a data distribution as close as possible to a Gaussian-type and to calculate more regular, i.e. easily interpretable, variograms during the structural analysis. In this respect, QQ-plots were drawn for a qualitative evaluation of the "normality" of the transformed variables. The comparison between the original and the transformed variables (see SM 3) shows that the latter approach produces a symmetrical distribution, although they cannot utterly be considered as Gaussian distributions, especially the $\log A$ s and $\log \mathrm{F}^{-}$ of thermal waters.

For each log-transformed variable, directional semi-variograms were computed for the estimation of the spatial variation of values of the regionalized variables (SM 4-6). Lag distances of $2500 \mathrm{~m}$ for $\mathrm{F}^{-}$and ${ }^{222} \mathrm{Rn}$ and $2000 \mathrm{~m}$ for As were used for computation, on the 
basis of the average minimum distance among pairs of samples. The geometric anisotropy for As is defined along the $\mathrm{N} 140^{\circ} \mathrm{E}$ and $\mathrm{N} 230^{\circ}$ E directions (SM 4), as representative of the major and minor axes of anisotropy ellipse, respectively. The major axis, representative of the direction of maximum spatial continuity of the variable, is at the range of $12,000 \mathrm{~m}$ whereas the minor axis, representative of the direction of maximum spatial variability of the variable, is at the range of $11,000 \mathrm{~m}$. As regards to $\mathrm{F}^{-}$, the main directions of the geometric anisotropy are $\mathrm{N} 160^{\circ} \mathrm{E}$ and $\mathrm{N} 250^{\circ} \mathrm{E}$ for maximum continuity (range of $9000 \mathrm{~m}$ ) and variability (range of $8500 \mathrm{~m}$ ), respectively (SM 5). The geometric anisotropy for ${ }^{222} \mathrm{Rn}$ is recognized along the $\mathrm{N} 170^{\circ} \mathrm{E}$ and $\mathrm{N} 260^{\circ} \mathrm{E}$ directions, for the major axis (range of $8500 \mathrm{~m}$ ) and the minor axis (range of $8000 \mathrm{~m}$ ), respectively (SM 6). Cross-validation results were checked for the three elements (SM 7) and afterwards estimation maps were processed through ordinary kriging.

\section{Discussion}

\subsection{Arsenic}

As shown by the contour map of Fig. 3, two main sectors characterized by high As concentrations were recognized $i$ ) along a NWSE-oriented belt roughly extending from Tuscania to Nepi and ii) to the south and east of the Bracciano lake. Both areas are characterized by the presence of several thermal waters fed by the deep reservoir, which have noticeably high As concentrations (Fig. 2a). Leaching of reservoir rocks may be invoked as the main source of As in thermal waters. Reservoir rocks in the study area are carbonateevaporite rocks, which are usually thought to have low As contents. However, as previously stated, different studies have highlighted the As uptake by calcite through the replacement of the carbonate group by As oxyanions. By assuming that the SVD and VCVD reservoir rocks have high As contents, intense leaching of Asbearing calcite at high temperatures, also favored by the presence of acidic gas species $\left(\mathrm{CO}_{2}, \mathrm{H}_{2} \mathrm{~S}\right)$ within the reservoir, can mobilize As, which can ultimately be discharged at the surface by the hydrothermal fluids. The high As concentration of thermal waters from the As-free sedimentary formations of the Tolfa mountains (samples no. 41, 71, 79, 82-84, 93, 94, 98, 132; see SM 1, 2) likely confirms that As is sourced from the deep reservoir. Nevertheless, chemical weathering of volcanic rocks may also significantly contribute to the As concentrations recorded in the thermal waters during their upflow towards the surface, since volcanic rocks from the Roman Magmatic Province are known to have high As contents and water-rock interaction processes are favored at high temperatures.

The upwelling of deep fluids from the hydrothermal reservoir is strictly related to the presence of structural elements (Fig. 3). Faulted and fractured zones provide permeable pathways to the fluid circulation within the crust and represent the fastest way through which deeper As-rich fluids can upraise towards the surface. During their ascent, interaction between hot fluids and As-rich volcanic rocks may provide additional As into solution. Whatever the source of As, faults represent the primary way through which As-rich hydrothermal fluids may mix with shallow groundwater

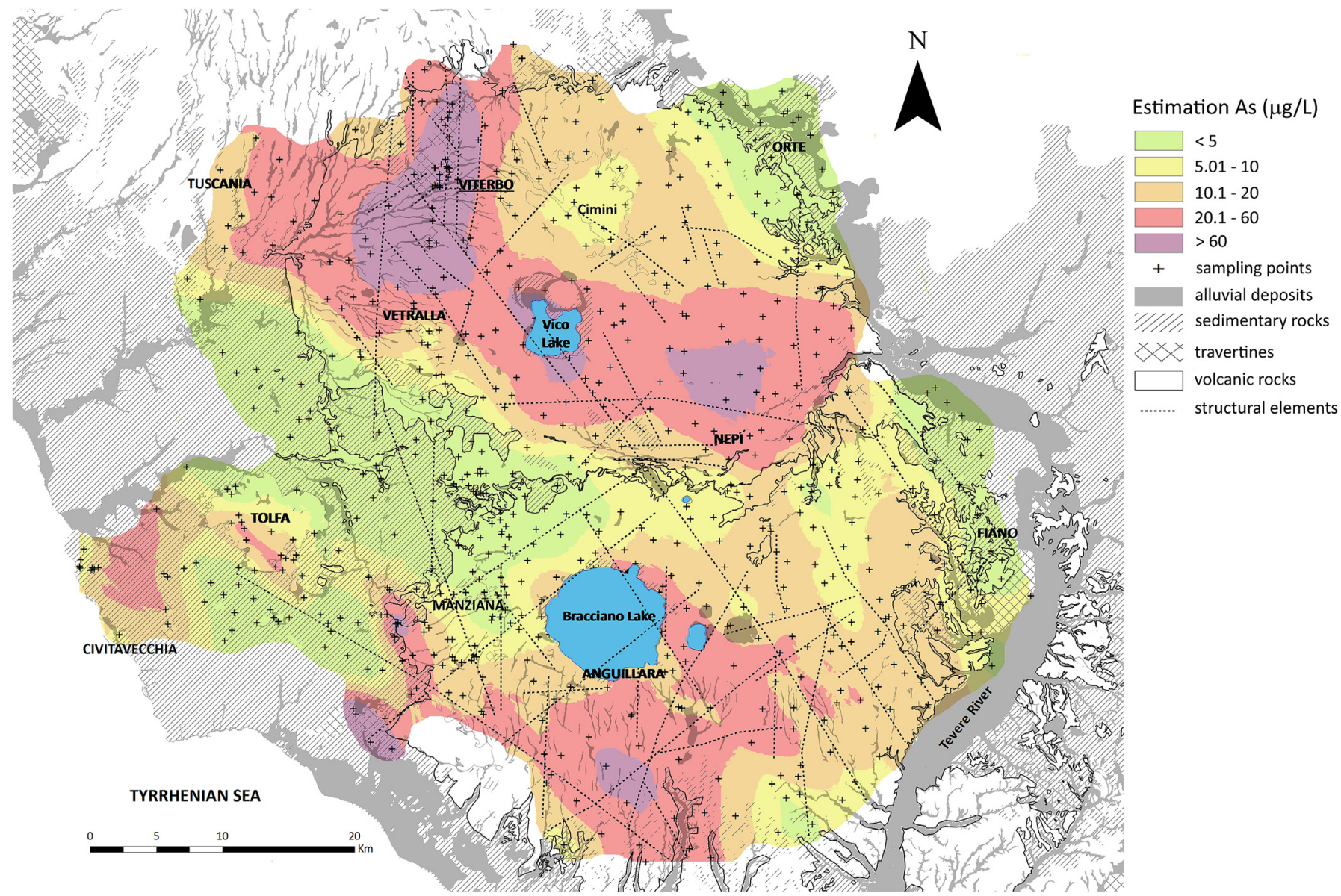

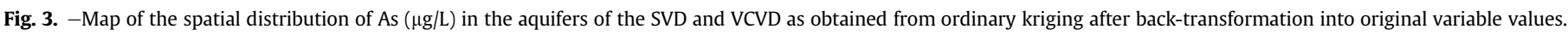
Structural elements simplified after Angelone et al. (2009) and De Rita et al. (2011). 
(see SM 2 for interpretative geological-hydrogeological cross-sections). Therefore, mixing with thermal waters represents the primary source of pollution of cold waters from the volcanic aquifer. Where high thicknesses of low-permeability sedimentary units and/or the lack of a fracture network prevent the communication between the volcanic and the hydrothermal aquifers, significantly lower As concentrations $(<20 \mu \mathrm{g} / \mathrm{L})$ within the volcanic aquifer were found. Specifically, this can be observed: $i$ ) in the northeastern sector of the VCVD from the Mts. Cimini to Orte and ii) in the large E-W-trending belt at the border between the SVD and the VCVD, roughly extending from Fiano to Manziana (Fig. 3). In these sectors, the concentration of As in the volcanic aquifer is primarily controlled by water-rock interaction processes and the length of the flow path. Despite the noticeably high As content in the rocks of the Roman Magmatic Province, weathering processes of volcanic rocks at low temperatures do not seem to significantly supply As to the groundwater system, in agreement with the results of leaching tests conducted on lavas and pyroclastic deposits from the VCVD (Armiento et al., 2015). Therefore, in the absence of a hydrothermal input, the slight differences of As concentration in the volcanic aquifer are likely influenced by $i$ ) the pristine As content and $i i$ ) the hydrogeological properties of lavas and pyroclastic units (i.e. fractured vs. porous media), the latter possibly exerting a stronger control on the circulation paths. Interestingly, where the groundwater flow path is more affected by human activities, e.g. where the over-exploitation of wells induces a steeper vertical gradient, the lateral inflow of As-rich waters may affect uncontaminated sectors (Baiocchi et al., 2013).
The remarkably low As concentrations $(<5 \mu \mathrm{g} / \mathrm{L})$ in waters circulating within the perched aquifers are likely due to the paucity of As in the sedimentary formations. However, as hydrothermal travertines are considered potential sources of significant amounts of As, their dissolution under acidic conditions characterizing the thermal and $\mathrm{CO}_{2}$-rich fluids discharging in the study area may provide an additional source of As into solution. This possibly explains the highest As concentrations (up to $625 \mu \mathrm{g} / \mathrm{L}$ ) of thermal waters emerging in correspondence of travertine deposits (the Viterbo area and samples no. 41, 71, 98, 132; SM 1, 2). Summarizing, mixing with As-rich thermal fluids and leaching of volcanicsedimentary host rocks represent the sources that mostly contribute to the As contamination of shallow groundwater.

\subsection{Fluoride}

The spatial distribution of $\mathrm{F}^{-}$concentrations (Fig. 4) is quite similar with that of As, likely due to their similar geochemical behavior. Consistently, $\mathrm{F}^{-}$is preferential enriched in thermal waters relative to cold waters due to its enhanced mobilization in the water-rock interaction processes at high temperatures. As for arsenic, the occurrence of high amounts of dissolved $\mathrm{F}^{-}$in the thermal waters (Fig. 2c), coupled with their upflow from the deep hydrothermal reservoir to the surface along the regional and/or local fracture network, is responsible for the contamination of the groundwater resource. In addition, the hydrothermal circulation is also associated with the presence in the study area of large F-rich deposits (Fig. 4), F-rich travertines and altered volcanic rocks.

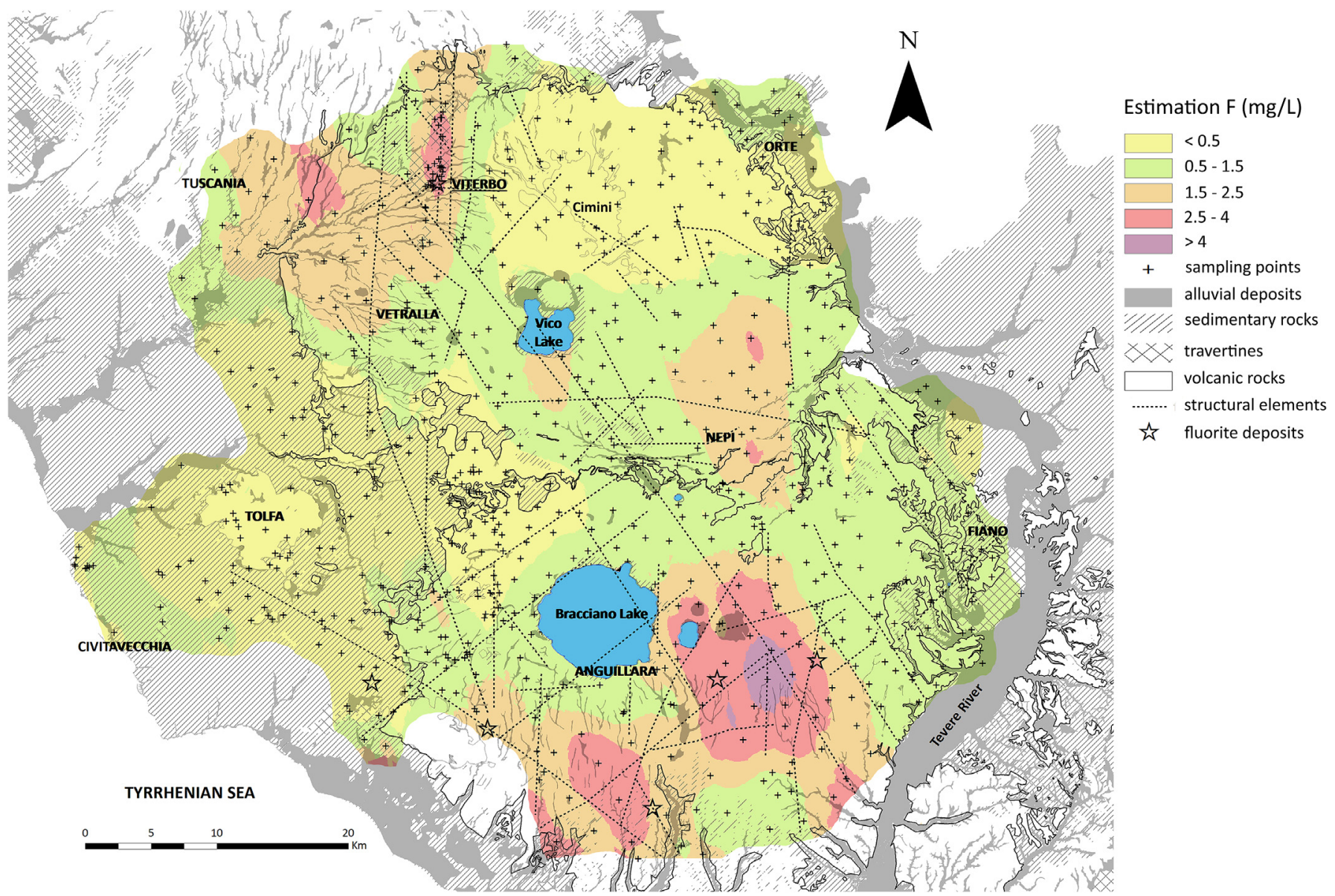

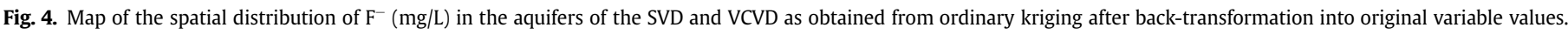
Structural elements simplified after Angelone et al. (2009) and De Rita et al. (2011). Position of fluorite deposits taken from De Rita et al. (2011). 
Leaching of these F-bearing rocks by shallow cold waters is particularly intense in the presence of an acidic $\left(\mathrm{CO}_{2}, \mathrm{H}_{2} \mathrm{~S}\right)$ gas phase, which lowers the $\mathrm{pH}$ to significantly low values (down to 2.4 $\mathrm{pH}$ units) and consequently increases the rock dissolution rate bringing anomalously amounts of $\mathrm{F}^{-}$(up to $16.5 \mathrm{mg} / \mathrm{L}$ ) into solution, even in the absence of a thermal circulation. Summarizing, the highest $\mathrm{F}^{-}$concentrations in the waters from the volcanic aquifer, i.e. above the concentration limit for drinkable waters $(>1.5 \mathrm{mg} / \mathrm{L})$, may be related to $i$ ) mixing with thermal F-rich waters and ii) leaching of F-rich deposits and/or hydrothermally altered rocks. On the other hand, $\mathrm{F}^{-}$mobility is limited in the absence of active hydrothermal and alteration processes, as suggested by results of leaching tests on SVD and VCVD rocks (De Rita et al., 2011), likely due to the low solubility of common F-bearing minerals of volcanic rocks (e.g. fluorite, fluorapatite). Interestingly, as leaching of pyroclastic rocks demonstrated to be more effective than that of lavas in terms of $\mathrm{F}^{-}$dissolution, likely due to the different hydrogeological properties of porous and fractured media on water-rock interaction processes, generally higher $(0.5-1.5 \mathrm{mg} / \mathrm{L}) \mathrm{F}^{-}$concentrations were observed for waters circulating within the pyroclastic units relative to those emerging from lavas $(\leq 0.5 \mathrm{mg} / \mathrm{L})$. Waters circulating within the sedimentary environment, where the background values of $\mathrm{F}^{-}$were estimated to be lower than those related to the volcanic rocks, show $\mathrm{F}^{-}$contents generally lower than the threshold value of $0.5 \mathrm{mg} / \mathrm{L}$. Mobilization of $\mathrm{F}^{-}$under acidic $(\mathrm{pH}<5)$ and alkaline conditions $(\mathrm{pH}>8.1)$ may explain the anomalously high $\mathrm{F}^{-}$concentrations (up to $3.8 \mathrm{mg} / \mathrm{L}$ ) of few waters emerging from sedimentary deposits (SM 1, 2).

\subsection{Radon}

The contour map of ${ }^{222} \mathrm{Rn}$ in groundwater (Fig. 5) is significantly different with respect to those of As and $\mathrm{F}^{-}$. It shows a preferential ${ }^{222} \mathrm{Rn}$ enrichment in the cold waters circulating within the volcanic rock aquifers, thus suggesting that the aquifer lithology is the main factor controlling the ${ }^{222} \mathrm{Rn}$ distribution in the study area (Fig. $2 \mathrm{~d}$ ). This is confirmed by the significantly higher mean contents of Rngenerating radionuclides ${ }^{238} \mathrm{U}$ and ${ }^{226} \mathrm{Ra}$ of tuffs and lavas from the Roman Magmatic Province relative to those of sedimentary formations. Significant variations in the distribution map were also highlighted between the innermost areas, including the Cimini Dome and the Vico and Bracciano depressions, where ${ }^{222} \mathrm{Rn}$ contents were often $>100 \mathrm{~Bq} / \mathrm{L}$ (i.e. higher than the parametric recommended value for drinking waters), and the peripheral areas, where concentrations were generally lower $(20-60 \mathrm{~Bq} / \mathrm{L})$. By assuming that the mean distribution of ${ }^{222} \mathrm{Rn}$ progenitors in the volcanic rocks is quite homogeneous, as evidenced by the comparable concentrations of ${ }^{238} \mathrm{U}$ and ${ }^{226} \mathrm{Ra}$ measured in tuffs and lavas, the heterogeneous distribution of ${ }^{222} \mathrm{Rn}$ concentrations in the volcanic aquifer likely results from different processes, including: $i$ ) the leaching of U-rich deposits, which are produced from secondary precipitation of $U$ mobilized from the groundmass of the volcanic rocks (Fig. 5); ii) the occurrence and distribution of a significant fracture network, which are expected to be correlated to

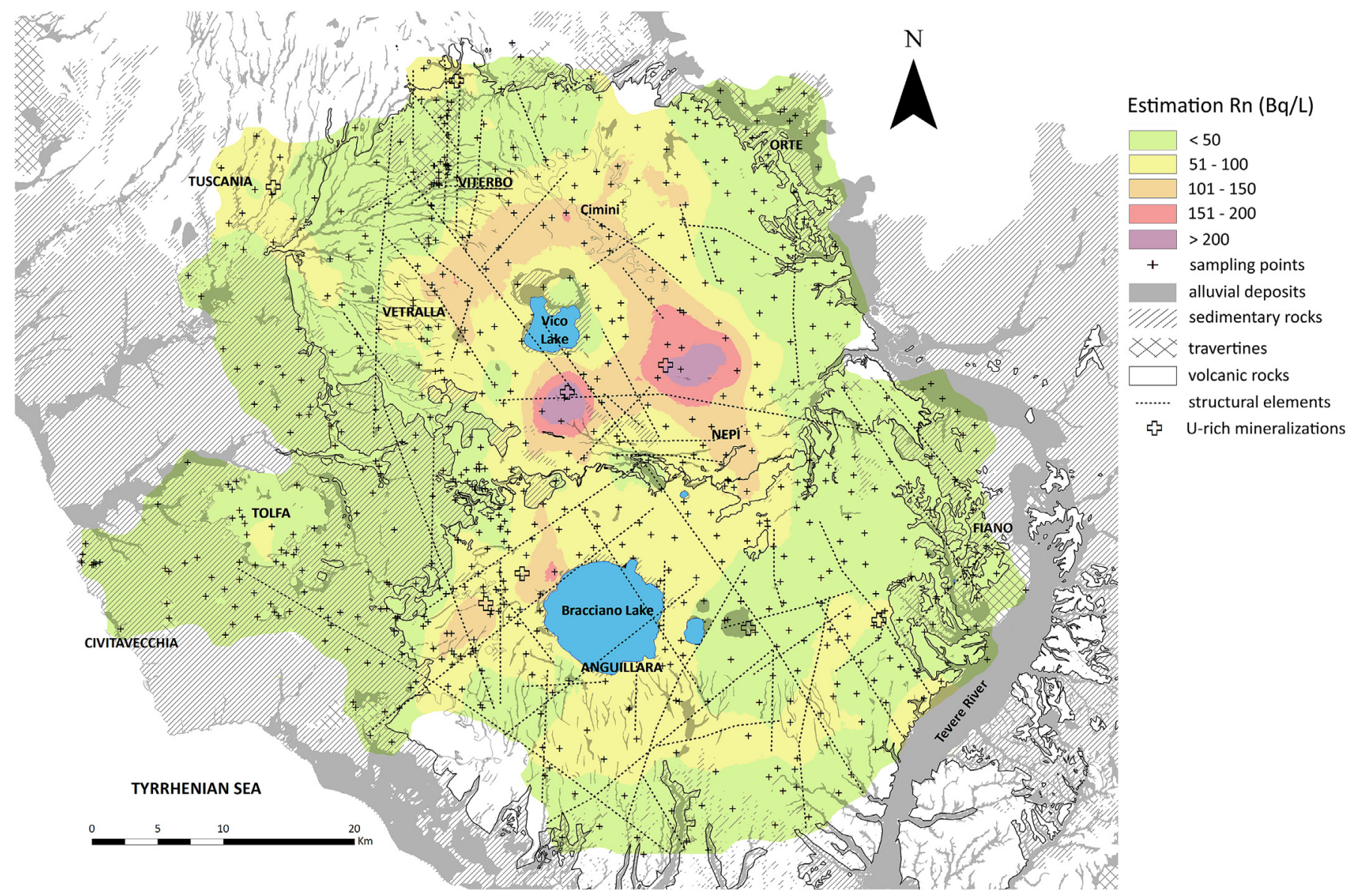

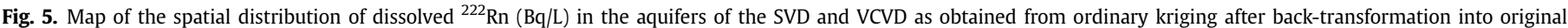

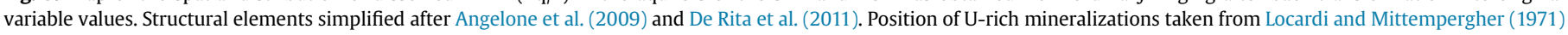
and Capannesi et al. (2012). 
higher ${ }^{222} \mathrm{Rn}$ concentrations since its mobility increases within fractured rocks; iii) the aquifer properties, which include the contact time between water and aquifer rock, transport processes in the groundwater, differences of transmissivity values, seasonal flow variations, distance to surface waters and/or waters from sedimentary aquifers. On the other hand, the significantly lower ${ }^{222} \mathrm{Rn}$ concentrations recorded in the thermal waters relative to coldvolcanic waters (Fig. 2d) are likely due to the fast decrease of ${ }^{222} \mathrm{Rn}$ solubility as water temperature increases. However, as thermal waters are commonly associated with a vigorous $\mathrm{CO}_{2}$-dominated gas phase uprising through fractures and faults (Cinti et al., 2011, 2014, 2017), the gas flux may exert a control on the transport of dissolved minor and trace gases, locally producing elevated ${ }^{222} \mathrm{Rn}$ concentrations (up to $698 \mathrm{~Bq} / \mathrm{L} ; \mathrm{SM} \mathrm{1,2).}$

\subsection{Health hazard evaluation and quality indexes for waters}

As regards to the elements considered in this study, mitigation actions within the SVD and the VCVD are presently focused only on the removal of As and $\mathrm{F}^{-}$from drinking waters, while for ${ }^{222} \mathrm{Rn}$ the recent guidelines issued by the Italian legal provisions (Legislative Decree $n^{\circ} 28 / 2016$ ) have not still been applied. The occurrence of large sectors of the study area where As and $\mathrm{F}^{-}$concentrations are largely exceeding the law limits forced policy makers and water resources managers to: $i$ ) an extensive application of water treatment techniques for their removal and ii) the discovery of new water resources of good quality. Water treatment techniques are primarily selected based on their ease of use. The main criticism concerns the high costs for removal of contaminants, including regeneration and/or disposal of treatment residues, which proportionally increases to the degree of contamination of water.

With the aim to provide a valuable tool for water management in a geogenically polluted area, including the discovery of new water resources to be used for human consumption and aimed at ensuring long-term compliance of the resource itself, a quality index (QI) for water samples was defined. QI consists of a number indicating the degree of quality of each sampled water, from the lowest $(\mathrm{QI}=1)$ to the highest $(\mathrm{QI}=4)$, based on the integrated As, $\mathrm{F}^{-}$and ${ }^{222} \mathrm{Rn}$ concentrations. The parametric approach used for the definition of the QI includes: $i$ ) identification of hazard concentration thresholds for each element, ii) definition of a quality index $\left(\mathrm{QI}_{\mathrm{X}}\right)$ relative to every single element for each water sample and $\left.i i i\right)$ integration of the three $\mathrm{QI}_{\mathrm{X}}$ for the processing of the final QI. The hazard concentration thresholds were established by both considering $i$ ) the adopted law limits for drinkable waters and $i i$ ) subjective limits, the latter being based on the concept of acceptable concentration, i.e. a concentration slightly higher than that fixed by law for which remediation interventions aimed at improving the quality of water can reasonably be achieved at lowcost. $\mathrm{QI}_{\mathrm{X}}$ values are reported in Table 2. For each element, the lower the $\mathrm{QI}_{\mathrm{X}}$ value the poorer the quality of water, the more complex the remediation actions are. It is noteworthy that waters with $\mathrm{F}^{-}$concentrations $<0.50 \mathrm{mg} / \mathrm{L}$, although drinkable in accordance with the Italian legal provisions, are outside the optimal range for human consumption $(0.50-1.5 \mathrm{mg} / \mathrm{L})$. Consequently, their $\mathrm{QI}_{\mathrm{x}}$ is one unit lower than the maximum value. The order of magnitude of $\mathrm{QI}_{\mathrm{X}}$ is different for each element; this is necessary for the processing of the final QI distribution map, in which each water sample is represented by the sum of three digits, the first one representing the $\mathrm{QI}_{\mathrm{x}}$ of As, the second that of $\mathrm{F}^{-}$and the third one that of ${ }^{222} \mathrm{Rn}$. The resulting QI distribution map is reported in Fig. 6. Arsenic is the key parameter used to define the final QI for each water sample (Table 3), basically because its toxicity is higher than that of $\mathrm{F}^{-}$and

${ }^{222} \mathrm{Rn}$ at the concentrations measured in the study area and treatment plants for its removal are more expensive. In the map, the areas showing $\mathrm{QI}=1$ refer to low and very low quality waters for human consumption, since As concentrations $(>50 \mu \mathrm{g} / \mathrm{L})$ are considerably exceeding the limit fixed by law $(10 \mu \mathrm{g} / \mathrm{L})$. Very lowquality waters (Fig. 6; Table 3), representing about the $77 \%$ of the total of this group, have also high $\mathrm{F}^{-}$concentrations $(>1.5 \mathrm{mg} / \mathrm{L})$ and, less frequently, high ${ }^{222} \mathrm{Rn}$ concentrations (about the $21 \%$ ). Remediation actions could generally be complex and expensive. Areas with $\mathrm{QI}=2$ are characterized by low-to-medium quality waters, basically fixed by As concentrations within the range $20.1-50 \mu \mathrm{g} / \mathrm{L}$ (Table 2). More than half of the waters of this group has $\mathrm{F}^{-}$concentrations higher than the law limits, whereas for about one third of the total database As is the only contaminant exceeding the law limits (medium-to-low quality waters; Fig. 6). As already stated, water treatments for the removal of contaminants are necessarily more or less complex and expensive according to $i$ ) As concentration and ii) occurrence of high $\mathrm{F}^{-}$(and sometimes ${ }^{222} \mathrm{Rn}$ ) concentrations. Areas with $\mathrm{QI}=3$ are characterized by medium and medium-to-high quality waters fixed by As concentrations within the range $10.1-20 \mu \mathrm{g} / \mathrm{L}$. Medium quality waters are those characterized by $\mathrm{F}^{-}$concentrations (about the $25 \%$ of the total) or ${ }^{222} \mathrm{Rn}$ concentrations (about the 20\%) above the law/recommended limits, while medium-to-high quality waters are those for which remediation actions can be planned limitedly to the As concentrations. Areas with $\mathrm{QI}=4$ are fixed by As concentrations $<10 \mu \mathrm{g} / \mathrm{L}$, i.e. below the law limit for human consumption. This group includes high- and very high-quality waters (Fig. 6), the latter including about the $84 \%$ of the total, and a few waters characterized by $\mathrm{F}^{-}$or ${ }^{222} \mathrm{Rn}$ concentrations higher than the law/recommended limits (about the $5 \%$ and $11 \%$, respectively). The latter can still be considered high quality waters, basically because water treatments do not involve As. It is noteworthy that $\mathrm{F}^{-}$concentrations within the optimum range for human health $(0.50-1.50 \mathrm{mg} / \mathrm{L})$ are only represented by $31 \%$ of high-quality waters, while for the remaining $69 \%$ the concentrations are within the quality standards for human consumption but below $0.50 \mathrm{mg} / \mathrm{L}$. Despite the fact that waters

Table 2

$\mathrm{QI}_{\mathrm{x}}$ values for the selected elements. Concentration ranges are expressed as $\mu \mathrm{g} / \mathrm{L}$ for As, $\mathrm{mg} / \mathrm{L}$ for $\mathrm{F}^{-}$and $\mathrm{Bq} / \mathrm{L}$ for ${ }^{222} \mathrm{Rn}$.

\begin{tabular}{|c|c|c|c|}
\hline Element & Concentration range & $\mathrm{QI}_{\mathrm{x}}$ & Notes \\
\hline \multirow[t]{4}{*}{ Arsenic } & $0-10$ & 500 & good quality (within the law limits) \\
\hline & $10.1-20$ & 300 & poor quality, slightly above law limits, remediation is generally simple and cheap \\
\hline & $20.1-50$ & 200 & poor quality, above law limits, remediation is generally more complex \\
\hline & $>50$ & 100 & bad quality, well above law limits, remediation is very complex and expansive \\
\hline \multirow[t]{5}{*}{ Fluoride } & $0-0.49$ & 40 & good quality, but concentration below law limits \\
\hline & $0.50-1.5$ & 50 & good quality (within the law limits) \\
\hline & $1.51-3$ & 30 & poor quality, slightly above law limits, remediation is generally simple and cheap \\
\hline & $>3$ & 20 & poor quality, above law limits, remediation is generally more complex \\
\hline & $0-100$ & 5 & good quality (within the law limits) \\
\hline \multirow[t]{2}{*}{ Radon } & $101-200$ & 3 & poor quality, slightly above recommended limits, remediation is generally simple and cheap \\
\hline & $>200$ & 2 & poor quality, above recommended limits, remediation is generally more complex \\
\hline
\end{tabular}




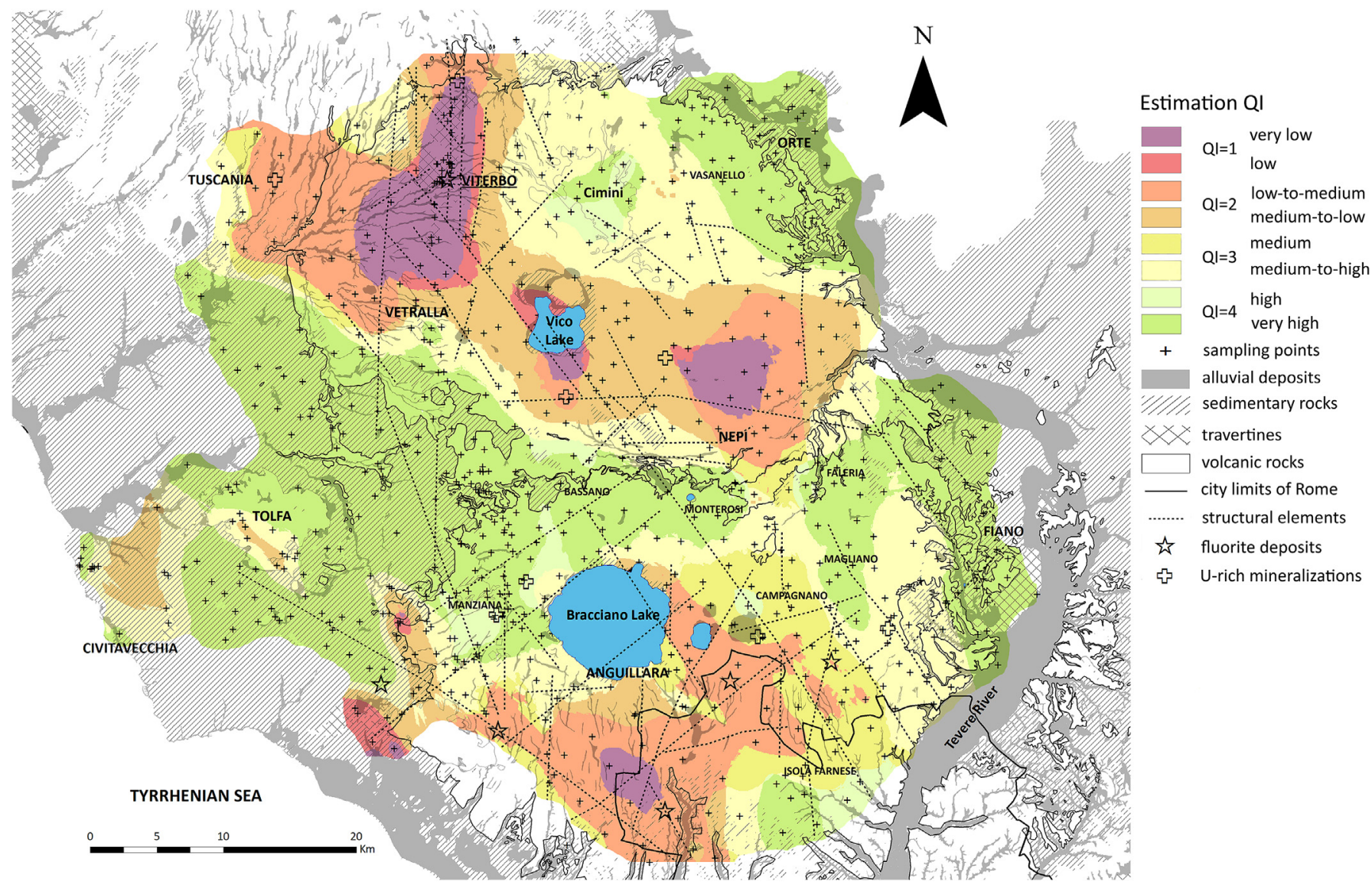

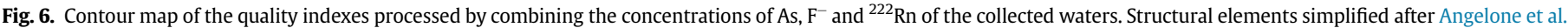
(2009) and De Rita et al. (2011). Position of fluorite deposits taken from De Rita et al. (2011).

Table 3

Possible combinations of the partial quality indexes for the final QI processing. The $\mathrm{QI}_{\mathrm{As}}$ was considered as the main parameter for the definition of the global QI of each sampled water.

\begin{tabular}{|c|c|c|}
\hline QI & $\mathrm{QI}_{\mathrm{x}}$ & Notes \\
\hline $1 \mathrm{a}$ & $\mathrm{QI}_{\mathrm{As}}=100, \mathrm{QI}_{\mathrm{F}} \leq 30, \mathrm{QI}_{\mathrm{Rn}} \leq 3$ & very low quality \\
\hline $1 b$ & $\mathrm{QI}_{\mathrm{As}}=100, \mathrm{QI}_{\mathrm{F}} \leq 30, \mathrm{QI}_{\mathrm{Rn}}=5$ & very low quality \\
\hline 1c & $\mathrm{QI}_{\mathrm{As}}=100, \mathrm{QI}_{\mathrm{F}} \geq 40, \mathrm{QI}_{\mathrm{Rn}} \leq 3$ & low quality \\
\hline $1 d$ & $\mathrm{QI}_{\mathrm{As}}=100, \mathrm{QI}_{\mathrm{F}} \geq 40, \mathrm{QI}_{\mathrm{Rn}}=5$ & low quality \\
\hline $2 a$ & $\mathrm{QI}_{\mathrm{As}}=200, \mathrm{QI}_{\mathrm{F}} \leq 30, \mathrm{QI}_{\mathrm{Rn}} \leq 3$ & low-to-medium quality \\
\hline $2 b$ & $\mathrm{QI}_{\mathrm{As}}=200, \mathrm{QI}_{\mathrm{F}} \leq 30, \mathrm{QI}_{\mathrm{Rn}}=5$ & low-to-medium quality \\
\hline $2 c$ & $\mathrm{QI}_{\mathrm{As}}=200, \mathrm{QI}_{\mathrm{F}} \geq 40, \mathrm{QI}_{\mathrm{Rn}} \leq 3$ & medium-to-low quality \\
\hline $2 d$ & $\mathrm{QI}_{\mathrm{As}}=200, \mathrm{QI}_{\mathrm{F}} \geq 40, \mathrm{QI}_{\mathrm{Rn}}=5$ & medium-to-low quality \\
\hline $3 a$ & $\mathrm{QI}_{\mathrm{As}}=300, \mathrm{QI}_{\mathrm{F}} \leq 30, \mathrm{QI}_{\mathrm{Rn}} \leq 3$ & medium quality \\
\hline $3 b$ & $\mathrm{QI}_{\mathrm{As}}=300, \mathrm{QI}_{\mathrm{F}} \leq 30, \mathrm{QI}_{\mathrm{Rn}}=5$ & medium quality \\
\hline $3 c$ & $\mathrm{QI}_{\mathrm{As}}=300, \mathrm{QI}_{\mathrm{F}} \geq 40, \mathrm{QI}_{\mathrm{Rn}} \leq 3$ & medium-to-high quality \\
\hline $3 d$ & $\mathrm{QI}_{\mathrm{As}}=300, \mathrm{QI}_{\mathrm{F}} \geq 40, \mathrm{QI}_{\mathrm{Rn}}=5$ & medium-to-high quality \\
\hline $4 a$ & $\mathrm{QI}_{\mathrm{As}}=500, \mathrm{QI}_{\mathrm{F}} \leq 30, \mathrm{QI}_{\mathrm{Rn}}=5$ & high quality \\
\hline $4 \mathrm{~b}$ & $\mathrm{QI}_{\mathrm{As}}=500, \mathrm{QI}_{\mathrm{F}} \geq 40, \mathrm{QI}_{\mathrm{Rn}} \leq 3$ & high quality \\
\hline $4 c$ & $\mathrm{QI}_{\mathrm{As}}=500, \mathrm{QI}_{\mathrm{F}}=40, \mathrm{QI}_{\mathrm{Rn}}=5$ & high quality \\
\hline $4 d$ & $\mathrm{QI}_{\mathrm{As}}=500, \mathrm{QI}_{\mathrm{F}}=50, \mathrm{QI}_{\mathrm{Rn}}=5$ & very high quality \\
\hline
\end{tabular}

hosted in the sedimentary aquifers are characterized by high QI (Fig. 6), their use for water supply purposes is difficult and/or limited to few potential users due to their modest thickness and limited lateral extension. On the other hand, the surface of areas characterized by high quality waters $(\mathrm{QI}=4)$ drastically decreases within the sectors occupied by volcanic deposits, which are those hosting the regional cold aquifer, which is the only one that can be exploited for the drinking water supply. Within the VCVD, suitable water resources $(\mathrm{QI}=4)$ for supplying drinking waters can be identified in the north-eastern sector, which includes the Mts. Cimini and houses from several villages and urban centers, including Orte ( $\sim 9000$ inhabitants). Medium-to-high quality waters $(\mathrm{QI}=3)$ could also be potentially suitable for human consumption if treated through low-cost removal techniques, such as mixing with non-contaminated waters that can be considered a valid alternative to de-arsenification. Within the SVD, high quality waters occur in the northern sector between Bassano and Monterosi, east of Bracciano Lake and in the north-eastern sector between Magliano and Faleria (Fig. 1). Medium-to-high quality waters can also be found in the surrounding areas.

\section{Concluding remarks}

The environmental geochemical cartography is a tool that is becoming increasingly important for the evaluation and mitigation of geogenic contamination of water resources as intended for human consumption, since it allows to both identify areas affected by anomalous concentrations of toxic elements for the environment and man and control and manage the territory. This tool is indeed effective in response to both environmental and health problems (such as the risk for humans deriving from drinking geogenically polluted waters) and economic problems including the intervention plans for water treatment and the discovery of good quality water resources. Moreover, it may also govern the management of agricultural and industrial activities, including the treatment and waste disposal, towards solutions aimed at the preservation of the sectors in which the contamination of water resources is minor or 
absent.

In this contest, the contour maps of As, $\mathrm{F}^{-}$and ${ }^{222} \mathrm{Rn}$ for the SVD and the VCVD volcanic-sedimentary aquifers were processed through the application of geostatistical methods on the geochemical data collected from (municipal, domestic) wells and springs during extensive sampling surveys. Waters hosted in the sedimentary units showed very low levels of contamination but, due to their ephemeral nature, they do not represent important resources for human consumption. In contrast, waters within the volcanic domain are affected by a strong geogenic contamination, which is mainly caused by the contribution of As- and F-rich fluids uprising through faulted and fractures zones from a deep hydrothermal reservoir and, to a lesser extent, by leaching of volcanic rocks and F- and U-rich deposits.

Since current practices for the removal of geogenic contaminants from water are expensive and do not guarantee long-term compliances of drinking waters, the processing of the acquired dataset for the definition of a quality index (QI) map, based on the integration of $\mathrm{As}, \mathrm{F}^{-}$and ${ }^{222} \mathrm{Rn}$ concentrations, may provide fundamental information for the development of intervention plans aimed at discovering new water resources for human consumption and mitigating the impact on groundwater quality.

\section{Acknowledgements}

All the municipalities are thanked for their help during the extensive field work. A special thank is due to the foresters of the Natural Parks whose territories are within the study area and to personnel of ACEA and TALETE companies. The authors also warmly thank three anonymous reviewers for their comments and suggestions that significantly improved an early version of the manuscript. This research did not receive any specific grant from funding agencies in the public, commercial, or not-for-profit sectors.

\section{Appendix A. Supplementary data}

Supplementary data to this article can be found online at https://doi.org/10.1016/j.envpol.2019.07.063.

\section{References}

Acocella, V., Funiciello, R., 2006. Transverse systems along the extensional Tyrrhenian margin of central Italy and their influence on volcanism. Tectonics 25. https://doi.org/10.1029/2005TC001845.

Aiuppa, A., Allard, P., D'Alessandro, W., Michel, A., Parello, F., Treuil, M., Valenza, M., 2000. Mobility and fluxes of major, minor and trace metals during basalt weathering and groundwater transport at Mt. Etna volcano (Sicily). Geochem. Cosmochim. Acta 64, 1827-1841.

Aiuppa, A., D'Alessandro, W., Federico, C., Palumbo, B., Valenza, M., 2003. The aquatic geochemistry of arsenic in volcanic groundwaters from southern Italy. Appl. Geochem. 18, 1283-1296.

Aiuppa, A., Federico, C., Allard, P., Gurrieri, S., Valenza, M., 2005. Trace metal modeling of groundwater-gas-rock interactions in a volcanic aquifer: Mount Vesuvius, southern Italy. Chem. Geol. 216, 289-311.

Aiuppa, A., Avino, R., Brusca, L., Caliro, S., Chiodini, G., D'Alessandro, W., Favara, R., Federico, C., Ginevra, W., Inguaggiato, S., Longo, M., Pecoraino, G., Valenza, M., 2006. Mineral control of arsenic content in thermal waters from volcano-hosted hydrothermal systems: insights from island of Ischia and Phlegrean Fields (Campanian Volcanic Province, Italy). Chem. Geol. 229, 313-330.

Allard, P., Aiuppa, A., Loyer, H., Carrot, F., Gaudry, A., Pinte, G., Michel, A., Dongarrà, G., 2000. Emission rate of metals and acid gases during long-lived basalt degassing at Stromboli volcano. Geophys. Res. Lett. 27, 1207-1210.

Alonso, H., Cruz-Fuentes, T., Rubiano, J.G., González-Guerra, J., del Carmen Cabrera, M., Arnedo, M.A., Tejera, A., Rodríguez-Gonzalez, A., Pérez-Torrado, F.J. Martel, P., 2015. Radon in groundwater of the northeastern Gran Canaria aquifer. Water 7, 2575-2590.

Andrews, J.N., Wood, D.F., 1974. Radium 226, radon 222 and lead 210 in bath thermal springs compared with some environmental waters. Health Phys. 27, 307-310.

Angelone, M., Cremisini, C., Piscopo, V., Proposito, M., Spaziani, F., 2009. Influence of hydrostratigraphy and structural setting on the arsenic occurrence in groundwater of the Cimino-Vico volcanic area (central Italy). Hydrogeol. J. 17, 901-914.

Armiento, G., Baiocchi, A., Cremisini, C., Crovato, C., Lotti, F., Lucentini, L., Mazzuoli, M., Nardi, E., Piscopo, V., Proposito, M., Veschetti, E., 2015. An integrated approach to identify water resources for human consumption in an area affected by high natural arsenic content. Water 7, 5091-5114.

Baiocchi, A., Dragoni, W., Lotti, F., Luzzi, G., Piscopo, V., 2006. Outline of the hy drogeology of the Cimino and Vico volcanic area and of the interaction between groundwater and lake Vico (Lazio Region, central Italy). Boll. Soc. Geol. It. 125, 187-202.

Baiocchi, A., Coletta, A., Espositi, L., Lotti, F., Piscopo, V., 2013. Sustainable groundwater development in a naturally arsenic-contaminated aquifer: the case of the Cimino-Vico volcanic area (central Italy). Ital. J. Eng. Geol. Environ. https:// doi.org/10.4408/IJEGE.2013-01.0-01.

Baldi, P., Decandia, F.A., Lazzarotto, A., Calamai, A., 1974. Studio geologico del substrato della copertura vulcanica laziale delle zone dei laghi di Bolsena, Vico e Bracciano. Mem. Soc. Geol. It. 13, 575-606.

Ball, T.K., Cameron, D.G., Colman, T.B., Roberts, P.D., 1991. Behaviour of radon in the geological environment: a review. Q. J. Eng. Geol. 24, 169-182.

Ballantyne, J.M., Moore, J.N., 1988. Arsenic geochemistry in geothermal systems. Geochem. Cosmochim. Acta 52, 475-483.

Barberi, F., Buonasorte, G., Cioni, R., Fiordelisi, A., Foresi, L., Iaccarino, S. Laurenzi, M.A., Sbrana, A., Vernia, L., Villa, I.M., 1994. Plio-Pleistocene geologica evolution of the geothermal area of Tuscany and Latium. Mem. Descr. Carta Geol. Ital. 49, 77-134.

Barbieri, M., Nigro, A., Sappa, G., 2014. Arsenic contamination in groundwater system of Viterbo area (central Italy). Senses Sci. 1, 101-106.

Bardelli, F., Benvenuti, M., Costagliola, P., Di Benedetto, F., Lattanzi, P., Meneghini, C., Romanelli, M., Valenzano, L., 2011. Arsenic uptake by natural calcite: an XAS study. Geochem. Cosmochim. Acta 75, 3011-3023.

Barnes, H.L. (Ed.), 1997. Geochemistry of Hydrothermal Ore Deposits, third ed. Wiley and Sons, New York, USA.

Bissen, M., Frimmel, F.H., 2003. Arsenic: a review - part I - occurrence, toxicity, speciation, mobility. Acta Hydrochim. Hydrobiol. 31, 9-18.

Bundschuh, J., Armienta, M.A., Birkle, P., Bhattacharya, P., Matschullat, J. Mukherjee, A.B. (Eds.), 2009. Natural Arsenic in Groundwaters of Latin America. Taylor \& Francis, London, UK.

Capannesi, G., Rosada, A., Manigrasso, M., Avino, P., 2012. Rare earth elements, thorium and uranium in ores of the North-Latium (Italy). J. Radioanal. Nucl. Chem. 291, 163-168.

Capelli, G., Mazza, R., Gazzetti, C., 2005. Strumenti e strategie per la tutela e l'uso compatibile della risorsa idrica nel Lazio: gli acquiferi vulcanici. Pitagora.

Choubisa, S.L., 1999. Chronic fluoride intoxication (fluorosis) in tribes and their domestic animals. Int. J. Environ. Stud. 36, 703-716.

Cimarelli, C., De Rita, D., 2006. Structural evolution of the Pleistocene Cimini trachytic volcanic complex (Central Italy). Bull. Volcanol. 68, 538-548.

Cinti, D., Procesi, M., Tassi, F., Montegrossi, G., Sciarra, A., Vaselli, O., Quattrocchi, F., 2011. Fluid geochemistry and geothermometry in the western sector of the Sabatini volcanic district and the Tolfa mountains (central Italy). Chem. Geol. 284, 160-181.

Cinti, D., Poncia, P.P., Procesi, M., Galli, G., Quattrocchi, F., 2013. Geostatistica techniques application to dissolved radon hazard mapping: an example from the western sector of the Sabatini volcanic district and the Tolfa Mountains (central Italy). Appl. Geochem. 35, 312-324.

Cinti, D., Tassi, F., Procesi, M., Bonini, M., Capecchiacci, F., Voltattorni, N., Vaselli, O., Quattrocchi, F., 2014. Fluid geochemistry and geothermometry in the unexploited geothermal field of the Vicano-Cimino volcanic district (central Italy). Chem. Geol. 371, 96-114.

Cinti, D., Poncia, P.P., Brusca, L., Tassi, F., Quattrocchi, F., Vaselli, O., 2015. Spatial distribution of arsenic, uranium and vanadium in the volcanic-sedimentary aquifers of the Vicano-Cimino Volcanic District (central Italy). J. Geochem. Explor. 152, 123-133.

Cinti, D., Tassi, F., Procesi, M., Brusca, L., Cabassi, J., Capecchiacci, F., Delgado Huertas, A., Galli, G., Grassa, F., Vaselli, O., Voltattorni, N., 2017. Geochemistry of hydrothermal fluids from the eastern sector of the Sabatini volcanic district central Italy). Appl. Geochem. 84, 187-201.

Cioni, R., Laurenzi, M.A., Sbrana, A., Villa, I.M., 1993. ${ }^{40} \mathrm{Ar}^{39}{ }^{39} \mathrm{Ar}$ chronostratigraphy of the initial activity in the Sabatini Volcanic Complex (Italy). Boll. Soc. Geol. It. $112,251-263$.

Clever, H.L., 2013. IUPAC Solubility Data Series. Krypton, Xenon and Radon - Gas Solubilities, vol. 2. Pergamon Press, Oxford, UK, p. 378.

Conticelli, S., Peccerillo, A., 1992. Petrology and geochemistry of potassic and ultrapotassic volcanism in central Italy: petrogenesis and inferences on the evolution of the mantle sources. Lithos 28, 221-240.

Costagliola, P., Bardelli, F., Benvenuti, M., Di Benedetto, F., Lattanzi, P., Romanelli, M. Paolieri, M., Rimondi, V., Vaggelli, G., 2013. Arsenic-bearing calcite in natura travertines: evidence from sequential extraction, $\mu$ XAS, and $\mu$ XRF. Environ. Sci. Technol. 47, 6231-6238.

Cothern, C.R., Rebers, P.A., 2014. Radon, Radium and Uranium in Drinking Water: Lewis Publishers, New York.

Council Directive 2013/51/EURATOM of 22 October, 2013. European Commission, Brussels. http://eur-lex.europa.eu/legal-content/EN/TXT/PDF/?uri=CELEX 32013L0051\&from=EN.

Council Directive 98/83/EC of 3 November, 1998. European Commission, Brussels http://eur-lex.europa.eu/LexUriServ/LexUriServ.do?uri=OJ:L:1998:330:0032: 
0054:EN:PDF.

Dall'Aglio, M., Giuliano, G., Amicizia, D., Andrenelli, M.C., Cicioni, G.B. Mastroianni, D., Sepicacchi, L., Tersigni, S., 2001. Assessing drinking water quality in northern Latium by trace elements analysis. In: Cidu, R. (Ed.), Proc. o the $10^{\text {th }}$ Int. Symp. on Water-Rock Interaction, Villasimius, Italy, pp. 1063-1066.

De Rita, D., Di Filippo, M., Rosa, C., 1996. Structural evolution of the Bracciano volcano-tectonic depression, Sabatini volcanic district, Italy. In: McGuire, W.C., et al. (Eds.), Volcano Instability on the Earth and Other Planets, vol. 110. Geol. Soc. Spec. Publication, pp. 225-236.

De Rita, D., Cremisini, C., Cinnirella, A., Spaziani, F., 2011. Fluorine in the rocks and sediments of volcanic areas in central Italy: total content, enrichment and leaching processes and a hypothesis on the vulnerability of the related aquifers. Environ. Monit. Assess. 184, 5781-5796.

Della Vedova, B., Bellani, S., Pellis, G., Squarci, P., 2001. Deep temperatures and surface heat flow distribution. In: Vai, G.B., Martini, P. (Eds.), Anatomy of an Orogen: the Apennines and Adjacent Mediterranean Basins, pp. 65-76.

Dubois, G., 2005. "An Overview of Radon Survey in Europe". Radioactivity Environmental Monitoring Emissions and Health Unit Institute for Environment and Sustainability JRC - European Commission. EUR 21892 EN, EC, p. 168.

D'Alessandro, W., 2006. Human fluorosis related to volcanic activity: a review. In: Kungolos, A.G., Brebbia, C.A., Samaras, C.P., Popov, V. (Eds.), Environmental Toxicology. WIT Press, Southampton, UK, pp. 21-30.

Edmunds, W.M., Smedley, P.L., 1996. Groundwater geochemistry and health: an overview. In: Appleton, J.D., Fuge, R., McCall, G.J.H. (Eds.), Environmental Geochemistry and Health, vol. 113. Geological Society Special Publ.

Ellis, A.J., Mahon, W.A.J., 1977. Chemistry and Geothermal Systems. Academic Press, New York.

Fabiani, L., Leoni, V., Vitali, M., 1999. Bone-fracture incidence rate in two Italian regions with different fluoride concentration levels in drinking water. J. Trace Elem. Med. Biol. 13, 232-237.

Faure, G., 1991. Principles and Applications of Inorganic Geochemistry. MacMillan Publ. Co., New York, NT, p. 626.

Fradà, G., Mentesana, G., Guaijani, U., 1969. Thyroid function in endemic hydrofluorosis in Sicily. Fluoride 2, 195-200.

Goovaerts, P., 1997. Geostatistics for Natural Resources Evaluation. Oxford University Press, New York.

Guo, H., Wang, Y., 2005. Geochemical characteristics of shallow groundwater in Datong basin, northwestern China. J. Geochem. Explor. 87, 109-120.

Hopke, P.K., Borak, T.B., Doull, J., Cleaver, E., Eckerman, K.F., Gundersen, L.C.S. Harley, N.H., Hess, C.T., Kinner, N.E., Kopecky, K.J., McKone, T.E., Sextro, R.G. Simon, S.L., 2000. Health risks due to radon in drinking water. Environ. Sci Technol. 34, 921-926.

IARC, 2004. International Agency for Research on Cancer. IARC monographs on the evaluation of carcinogenic risks to humans. In: Some Drinking-Water Disinfectants and Contaminants, Including Arsenic, ume 84 (Lyon).

Jagtap, S., Yenkie, M.K., Labhsetwar, N., Rayalu, S., 2012. Fluoride in drinking wate and defluoridation of water. Chem. Rev. 112, 2454-2466.

Katsoyiannis, I.A., Zouboulis, A.I., 2004. Application of biological processes for the removal of arsenic from groundwaters. Water Res. 38, 17-26.

Krige, D.G., 1966. Two dimensional weighted moving average trend surfaces for oreevaluation. J. S. Afr. Inst. Min. Metall 66, 13-38.

Laurenzi, M.A., Villa, I.M., 1987. ${ }^{40} \mathrm{Ar} /{ }^{39} \mathrm{Ar}$ chronostratigraphy of Vico ignimbrites. Period. Mineral. 56, 285-293.

Le Guern, C., Baranger, P., Crouzet, C., Bodénan, F., Conil, P., 2003. Arsenic trapping by iron oxyhydroxides and carbonates at hydrothermal spring outlets. Appl. Geochem. 18, 1313-1323.

Locardi, E., Mittempergher, M., 1971. Exhalative supergenic uranium, thorium and marcasite occurrences in quaternary volcanites of central Italy. Bull. Volcanol 35, 173-184.

Loomis, D.P., Watson, J.E., Crawford-Brown, D.J., 1988. Predicting the occurrence of radon-222 in groundwater supplies. Environ. Geochem. Health 10, 41-50.

Manca, F., Viaroli, S., Mazza, R., 2017. Hydrogeology of the Sabatini volcanic district (central Italy). J. Maps 13, 252-259.

Mancini, C., Quattrocchi, F., Guadoni, F., Pizzino, L., Porfidia, B., $2000 .{ }^{222}$ Rn study throughout different seismotectonical areas: comparison between different techniques for discrete monitoring. Ann. Geofisc. 43, 1-28.

Marra, F., Karner, D.B., Freda, C., Gaeta, M., Renne, P., 2009. Large mafic eruptions at Alban Hills Volcanic District (central Italy): chronostratigraphy, petrography and eruptive behavior. J. Volcanol. Geotherm. Res. 179, 217-232.

Matheron, G., 1971. The Theory of Regionalized Variables and its Applications. Cahiers du Centre de Morphologie Mathematique, Fontainbleau.

Meenakshi, S., Maheshwari, R.C., 2006. Fluoride in drinking water and its removal. J. Hazard Mater. 37, 456-463.

Mohan, D., Pittman, C.U., 2007. Arsenic removal from water/wastewater using adsorbents - a critical review. J. Hazard Mater. 142, 1-53.

Nordstrom, D.K. 2002. Worldwide occurrences of arsenic in ground water. Science 296, 2143-2145.

Norra, S., Berner, Z.A., Agarwala, P., Wagner, F., Chandrasekharam, D., Stüben, D. 2005. Impact of irrigation with as rich groundwater on soil and crops: geochemical case study in West Bengal Delta Plain, India. Appl. Geochem. 20, 1890-1906.

Oremland, R.S., Stolz, J.F., 2003. The ecology of arsenic. Science 300, 939-944.

Ozsvath, D.L., 2009. Fluoride and environmental health: a review. Rev. Environ. Sci.
Biotechnol. 8, 59-79.

Paone, A., Ayuso, R.A., De Vivo, B., 2001. A metallogenic survey of alkalic rocks of Mt Somma-Vesuvius volcano. Mineral. Petrol. 73, 201-233.

Peccerillo, A., 2017. Cenozoic Volcanism in the Tyrrhenian Sea Region. Springer International Publishing AG, Cham, Switzerland.

Pentecost, A., 1995. Geochemistry of carbon dioxide in six travertine-depositing water of Italy. J. Hydrol. 167, 263-278.

Piscopo, V., Armiento, G., Baiocchi, A., Mazzuoli, M., Nardi, E., Piacentini, S.M., proposito, M., Spaziani, F., 2018. Role of high-elevation groundwater flows in the hydrogeology of the Cimino volcano (central Italy) and possibilities to capture drinking water in a geogenically contaminated environment. Hydrogeol. J. https://doi.org/10.1007/s10040-017-1718-6.

Preziosi, E., Rossi, D. Parrone, D., Ghergo, S., 2016. Groundwater chemical status assessment considering geochemical background: an example from northern Latium (central Italy). Rend. Fis. Acc. Lincei 27, 59-66.

Procesi, M., Cantucci, B., Buttinelli, M., Armezzani, G., Quattrocchi, F., Boschi, E. 2013. Strategic use of the underground in an energy mix plan: synergies among $\mathrm{CO}_{2}, \mathrm{CH}_{4}$ geological storage and geothermal energy. Appl. Energy 110, 104-131.

Rahman, M.M., Sengupta, M.K., Ahamed, S., Chowdhury, U.K., Hossain, M.A., Das, B. Lodh, D., Saha, K.C., Pati, S., Kaies, I., Barua, A.K., Chakraborti, D., 2005. The magnitude of arsenic contamination in groundwater and its health effects to the inhabitants of the Jalangi: one of the 85 arsenic affected blocks in West Bengal, India. Sci. Total Environ. 338, 189-200.

Ravenscroft, P., Brammer, H., Richards, K. (Eds.), 2009. Arsenic Pollution: a Global Synthesis. John Wiley \& Sons, West Sussex, UK.

Reimann, C., Bjorvatn, K., Frengstad, B., Melaku, Z., Tekle-Haimanot, R., Siewers, U., 2003. Drinking water quality in the Ethiopian section of the East African Rift Valley I - data and health aspects. Sci. Total Environ. 311, 65-80.

Ren, F.R., Shugin, J., 1988. Distribution and formation of high-fluorine groundwater in China. Environ. Geol. Water Sci. 12, 3-10.

Roba, C.A., Codrea, V., Moldovan, M., Baciu, C., Cosma, C., 2000. Radium and radon content of some cold and thermal aquifers from Bihor country (northwestern Romania). Geofluids 10, 571-585.

Sawyer, G.M., Opperheimer, C., 2006. Volcanic fluorine emissions: observations by Fourier transform infrared spectroscopy. In: Tressaud, A. (Ed.), Fluorine and the Environment: Atmospheric Chemistry, Emissions, and Lithosphere. Elsevier, Amsterdam, The Netherlands.

Scrocca, D., Doglioni, C. Innocenti, F. 2003. Constraints for an interpretation of the Italian geodynamics: a review. Mem. Descr. Carta Geol. D'It. 62, 15-46.

Serri, G., Innocenti, F., Manetti, P., 1993. Geochemical and petrological evidence of the subduction of delaminated Adriatic continental lithosphere in the genesis of the Neogene-Quaternary magmatism of central Italy. Tectonophysics 223, $117-147$.

Smedley, P.L., Kinniburgh, D.G., 2002. A review of the source, behavior and distribution of arsenic in natural waters. Appl. Geochem. 17, 517-568.

Soto-Rojas, A.E., Ureña-Cirett, J.L., Martínez-Mier, E.A., 2004. A review of the prevalence of dental fluorosis in Mexico. Pan Am. J. Public Health 15, 9-17.

Stüben, D., Zsolt, B., Chandrasekharam, D., Karmakar, J., 2003. Arsenic enrichment in groundwater of West Bengal, India: geochemical evidence for mobilization of as under reducing conditions. Appl. Geochem. 18, 1417-1434.

Synnott, H., Fenton, D., 2005. An Evaluation of Radon Reference Levels and Radon Measurement Techniques and Protocols in European Countries. ERRICCA 2 Report. European Commission Contract No: FIRI-CT-2001-20142.

Trevisi, R., Bruno, M., Orlando, C., Ocone, R., Paolelli, C., Amici, M., Altieri, A., Antonelli, B., 2005. Radiometric characterization of more representative natural building materials in the province of Rome. Radiat. Prot. Dosim. 113, 168-172.

UNSCEAR (United Nations Scientific Committee on the Effects of Atomic Radiation), 2008. Sources and Effects of Ionizing Radiation. Report to General Assembly, Annex B, United Nations, New York City, NY, USA, p. 245.

Vaklavikov, M., Gallios, G.P., Hredzak, S., Jakabsky, S., 2008. Removal of arsenic from water streams: an overview of available techniques. Clean Technol. Environ. Policy 10, 89-95.

Viaroli, S., Cuoco, E., Mazza, R., Tedesco, D., 2016. Dynamics of natural contamination by aluminum and iron rich colloids in the volcanic aquifers of central Italy. Environ. Sci. Pollut. Res. 23, 19958-19977.

Vinson, D.S., Vengosh, A., Hirschfeld, D., Dwyer, G.S., 2009. Relationships between radium and radon occurrence and hydrochemistry in fresh groundwater from fractured crystalline rocks, North Carolina (USA). Chem. Geol. 260, 159-171.

Vivona, R. Preziosi, E., Madé, B., Giuliano, G. 2007. Occurrence of minor toxic elements in volcanic-sedimentary aquifers: a case study in central Italy. Hydrogeol. J. 15, 1183-1196.

Voltaggio, M., Di Lisa, G.A., Voltaggio, S., 2001. U-series disequilibrium study on a gaseous discharge area (Solforata di Pomezia, Alban Hills, Italy): implications for volcanic and geochemical risk. Appl. Geochem. 16, 57-72.

Webster, J.G., 1999. Arsenic. In: Marshall, C.P., Fairbridge, R.W. (Eds.), Encyclopedia of Geochemistry. Chapman Hall, London, pp. 21-22.

Weinstein, L.H., Davison, A., 2003. Fluoride in the Environment. CABI Publishing, Wallingford, UK.

WHO, 2011. Guidelines for Drinking-Water Quality, fourth ed. WHO Press, Geneva.

Winkel, L.H.E., Casentini, B., Bardelli, F., Voegelin, A., Nikolaidis, N.P., Charlet, L., 2013. Speciation of arsenic in Greek travertines: co-precipitation of arsenate with calcite. Geochem. Cosmochim. Acta 106, 99-110. 